\title{
Impact of Corporate Governance on American Corporates' Financial Performance: The Mediating Role of Derivatives
}

\author{
Salman Bahoo \\ Farhan Ahmed ${ }^{2}$ \\ Ayesha Shoukat \\ Mumtaz Ahmad ${ }^{4}$
}

\begin{abstract}
This study aims to present and test a model that derivatives (commodity, currency, and interest rate) play a mediating role between corporate governance and financial performance. We tested this model through a sample of 85 non-financial American corporates listed in New York Stock Exchange, U.S. 100 Index for six years from 2009-2014 by applying Partial Least Square, Structural Equation Modeling. We confirm that derivatives usage plays a mediating role between corporate governance and financial performance. We found and recommend that the utilization of derivatives as a risk management tool is essential for corporates to improve financial performance. Finally, the findings are useful for corporates from developed (European), emerging (China), and developing (Pakistan, Bangladesh) countries to utilize derivatives to hedge risk and improve financial performance.
\end{abstract}

JEL Classification: $G 34, G 3, D 22$

Keywords: Risk Management, Hedging, Derivatives, Corporate Governance

\section{INTRODUCTION}

Significant foreign direct investment through multinational corporates is a result of the globalization. Corporates are key players around the world and deal with several countries and currencies. The strong corporate governance and risk management mechanism is essential for national and multinational corporates to survive and improve financial performance (Prevost, Rose, \& Miller, 2000). The corporate governance has gain attention after considerable losses to big corporates such as Enron, Harris Scarfe, One. Tel, WorldCom, and Andersen. In the United States of America, the corporate governance became famous after the scandal of Watergate (the 1970s). As a result, the Sarbanes -Oxley Act 2002 and Dodd-Frank Act 2010 is passed in the US.

The association between the corporate governance and corporates financial performance is studied by several researchers (Jiang \& Zhang, 2018; Nawaz \& Ahmad, 2017; Paniagua, Rivelles, \& Sapena, 2018; Yilmaz, 2018; Shahwan, 2015). Most researchers found that corporate governance is essential and impacts positively towards the financial performance of the national and multinational corporates.

Further, the multinational corporates face a different type of risk, such as commodity prices, foreign currency, and interest rate risk while doing operations around the world. It is essential for the multinational corporates to have a sound risk management system to overcome these risks. The derivatives have a positive impact on financial performance (Erez-gonz, 2013; Donohoe, 2015; Kim, Papanastassiou, \& Nguyen, 2017; Bae, Kim, \& Kwon, 2018; Bahoo,

\footnotetext{
1,3,4- Department of Commerce, The Islamia University Bahawalpur - Pakistan Email: agm.ird@yahoo.com

2- Department of Economics \& Management Sciences, NED University of Engineering \& Technology, Karachi - Pakistan

\begin{tabular}{llll}
\hline JISR-MSSE & Volume 17 & Number 1 & January-June 2019 \\
\hline
\end{tabular}
} 
Khan, \& Ahmad et al., 2018). The utilization of three types of derivatives; currency, commodity, and interest rate are primary tools of risk management policy. However, several managers use derivatives contracts for speculation or for their benefit instead of the corporate that lead to the agency problem. It is emphasized that corporate governance is mandatory for efficient and appropriate use of derivatives by reducing agency problem (Allayannis et al., 2012).

Up till now, the causal effect of two variables is studied; such as corporate governance to financial performance (Nawaz \& Ahmad, 2017), corporate governance to risk management through derivatives usage (Adams et al., 2011), and risk management through derivatives usage to financial performance (Bahoo et al., 2018). However, a combined study on these three variables is conducted by the following two researchers. First, Allayannis et al. (2012) merely used corporate governance as a conditional variable where corporate governance is active derivatives usage add more value and vice versa. In another study by Aebi et al. (2011), they concluded that risk management has a positive impact on financial performance, but there is no association between corporate governance and financial performance during the crisis 2007-2008.

In this study, we want to extend the work of Bahoo et al. (2018) by examining the mediating role of derivatives between corporate governance and financial performance. We examined this model on American corporates. Our study is unique due to several aspects. First, this study tests the mediating effect of derivatives usage between corporate governance and financial performance. We test mediation based on criteria and theory of Helm et at. (2010), and Baron and Kenny (1986) because it is considered as a most appropriate way of analyzing the mediation through Structural Equation Modeling (Iqbal et al., 2017; Raj, 2018; Wo, Cheng \& $\mathrm{Ai}, 2017)$. Second, we examine the American corporates listed in New York Stock Exchange (NYSE)-US 100 Index from 2009-2014 by following Bahoo et al. (2018).

The sample of the study is unique as these 100 American corporates cover $36 \%$ of the market capitalization of the NYSE (NYSE, 2018). Third, to avoid the effect of economic and financial crises effect, we choose a period of study between 2009-2014 (Bahoo et al., 2018). Fourth, we applied Partial Least Square, Structural Equation Modeling (PLS-SEM) to examine this model (Iqbal et al., 2017; Fiksenbaum et al., 2017).

Our study has multiple findings. First, we found that corporate governance has a positive association with the financial performance during 2009 to 2014 same as per findings of Jiang and Zhang (2018). Second, our analysis shows that corporate governance has an impact on the proper utilization of the derivatives usage by managers to reduce the agency problem for six years, like Clark and Meftah (2010). Third, we found that derivatives have a positive effect on financial years from 2010 to 2014 but not in 2009. This result is like our precious study Bahoo et al. (2018). Forth, we found that derivatives play mediating role in years 2014, 2013, 2010, 2011 and unable to play in 2012 and 2009. The reason behind the no mediation effect in 2012 and 2009 is the financial crises of 2007-2008 and Euro-Zone crisis 2012 (Erkens et al., 2010; Eurozone crisis explained, 2012). Because the positive effect added by derivatives to minimize the risk has nullified by these crises, and our hypothesis gets rejected in 2009 and 2012.

The rest of the articles organizes as follows: section 2 explains the literature review and theoretical model, and section 3 presents the methodology and data analysis. Section 4 shows the discussion and conclusion.

126 January-June $2019 \quad$ Volume $17 \quad$ Number $1 \quad$ JISR-MSSE




\section{LITERATURE REVIEW AND THEORETICAL MODEL}

\section{Corporate Governance}

The relationship between corporate governance and financial performance is checked by Nguyen et al. (2015) during the financial crises 2007-08 and concluded that corporate governance played a proper role and saved firms from adverse shocks. In the U.S the corporate governance is a vital topic of study and Sarbanes -Oxley, Act, 2002 and Dodd-Frank, Act, 2010 are implemented to reduce the agency problem.

\section{Derivatives Usage}

The use of derivatives as a risk management tool is one of the essential techniques that corporates use in an era of globalization that minimize risk and increase firm value (Bessembinder, 1991; Nguyen, Kim, \& Papanastassiou, 2018). In U.S. corporates is one of the essential users of derivatives around the world and U.S. derivatives market has improved up to \$ 308 trillion in 2012 and almost equal to double of U.S. GDP as reported by Bank of International Settlements.

\section{Financial Performance}

The financial performance is a critical indicator that a business is working well, and different proxies are used by various researchers for financial performance (Bae, Kim, \& Kwon, 2018). The selection of unbiased indicators to measure financial performance is significant.

\section{Corporate Governance and Financial Performance}

Connelly, Limpaphayom, and Nagarajan et al. (2012) examined the relationship between the corporate governance and firm value of Thai-firms and concluded that good corporate governance adds in firm value. Yang and Zhao (2014) also conducted a study on Canadian and U.S corporates by using 1989 Canada-United State Free Trade Agreement as shock and found that corporates with CEO duality outer perform as compared to non-dual and concluded that corporate governance has a positive impact on firm value. Many researchers found a positive relationship (Chhaochharia \& Grinstein, 2007; Ferrer \& Banderlipe, 2012; Paniagua et al., 2018; Yilmaz, 2018) and some found the opposite (Velnampy, 2013). We draw our first hypothesis as;

H1: Corporate Governance is positively and significantly related to Financial Performance.

\section{Corporate Governance and Derivatives usage}

Corporate Governance and risk management had been discussed side by side in the early years especially, after a default of big companies such as Bear Stearns and Lehman Brothers. According to a survey of the World Bank in 2004 good corporate governance plays a vital role while managing the risk effectively (Adams et al., 2011). Lel (2012) studied 30 countries and concluded that for proper utilization of derivatives and avoid agency problem good corporate governance is a must. In the U.S., it is likely that manager use derivatives for a personal reason instead of hedging (Bodnar \& Marston, 1998) and good governance are required. Thus, the following hypothesis has been formulated;

\begin{tabular}{llll}
\hline JISR-MSSE & Volume 17 & Number 1 & January-June 2019 \\
\hline
\end{tabular}


H2: Corporate Governance is positively \& significantly related to Derivatives usage.

\section{Derivatives usage and Financial Performance}

Recently, Bahoo et al. (2018) analyzed the effect of derivatives usage on financial performance on American corporates and found positive effects. Similarly, Allayannis and Weston (2001) examined 720 non-financial U.S corporates and found a positive impact on firm value. The hedging of risk through derivatives add premium and improve firm value (Fok, Carroll, \& Chiou, 1997; Clark \& Meftah, 2010), and few researchers also have contrary findings (Fok et al., 1997; Ayturk, Gurbuz \&Yanik, 2016). In light of previous studies, the following hypothesis designed.

H3: The Derivatives usage is positively \& significantly related to financial performance.

\section{Corporate Governance, Derivatives usage, and Financial Performance}

There are few studies which examine these three variables together. First, Aebi et al. (2011) which examine a relationship among risk management, corporate governance, and performance during crises of 2007-08. They recommended that corporates with substantial risk related governance have excellent performance and vice versa. Second, Allayannis et al. (2012) used corporate governance as a conditional variable and found that where corporate governance is strong derivatives add more premium as compared to the weak governance of corporates. Third, Ahmed et al. (2012) find that risk management and corporate governance are interlinked to improve performance. Finally, the three variables, such as derivatives as a risk management tool, board effectiveness as corporate governance's part, and firm value are tested together on a sample of Australian corporates by Kommunuri et al. (2014).

Therefore, the limited research work on these variables and literature support enabled the researcher to conceptualize a new theoretical model that derivatives play a mediating role between corporate governance and financial performance (See Figure 1). We developed the following hypothesis.

H4: Derivatives usage work as mediator between Corporate Governance and Financial Performance.

The list of hypothesis and details of variables are given in Tables 1 and 2.

Table 1: List of Hypothesis

\begin{tabular}{cll}
\hline Hypothesis & Description & Codes \\
\hline H1 & $\begin{array}{l}\text { Corporate Governance is positively and } \\
\text { significantly related to Financial Performance. }\end{array}$ & (CORP_GOV $\rightarrow$ FIN_PERF). \\
H2 & $\begin{array}{l}\text { Corporate Governance is positively \& } \\
\text { significantly related to Derivatives usage. }\end{array}$ & $\begin{array}{l}\text { (CORP_GOV } \rightarrow \text { DERV) } \\
\text { H3 }\end{array}$ \\
The Derivatives usage is positively \& & $\begin{array}{l}\text { significantly related to financial performance. } \\
\text { Derivatives usage work as mediator between } \\
\text { Corporate Governance and Financial Performance. }\end{array}$ & $\begin{array}{l}\text { (DERV } \rightarrow \text { FIN_PERF) } \\
\text { (CORP_GOV } \rightarrow \text { DERV } \rightarrow\end{array}$ \\
\hline
\end{tabular}

Note: Table 1 shows the list of hypotheses developed by the authors to check the mediating role of derivatives between corporate governance and financial performance based on the criteria of Helm et at. (2010) and Baron and Kenny (1986).

128 January-June $2019 \quad$ Volume $17 \quad$ Number 12 JISR-MSSE


Table 2: Details of Variables

\begin{tabular}{|c|c|c|c|c|c|}
\hline Construct & Indicator & Code & Symbol & Measuremeat & Refereace \\
\hline \multirow[b]{3}{*}{$\begin{array}{l}\text { Latent } \\
\text { Exogenous }\end{array}$} & 1-Board Meeting (BRD_MEET) & CGI & $\gamma_{\mathrm{x} 1}$ & No of Boand Meetings: & (Shan, 2013) \\
\hline & 2- Female Director (FEMALE_DR) & CG2 & $\gamma_{n} 2$ & No of Female Director & (Faleye, 2007) \\
\hline & $\begin{array}{l}\text { 3-Audit Committee } \\
\text { (AUDIT_COM) }\end{array}$ & CG3 & yos & $\begin{array}{l}\text { No of audit committee } \\
\text { members }\end{array}$ & $\begin{array}{l}\text { (Gupta \& Sharma, } \\
\text { 2014) }\end{array}$ \\
\hline \multirow{3}{*}{$\begin{array}{l}\text { Corporate } \\
\text { Governance } \\
\text { (CORP_GOV) } \\
\text { Symbol: } \xi\end{array}$} & $\begin{array}{l}\text { 4-Compensation Committee } \\
\text { (COMPEN_COM) }\end{array}$ & CG4 & $\gamma_{\mathrm{x} 4}$ & $\begin{array}{l}\text { No of compensation } \\
\text { committee members }\end{array}$ & $\begin{array}{l}\text { (Black \& Kimb, } \\
\text { 2012) }\end{array}$ \\
\hline & $\begin{array}{l}\text { 5-Management Remuneration } \\
\text { (MG_REMUN_LN) }\end{array}$ & CG5 & $\gamma_{x s}$ & $\begin{array}{l}\text { Natural Log of } \\
\text { Maragement Remuneration } \\
\text { in term of U.S Dollars }\end{array}$ & $\begin{array}{l}\text { (Makki \& Lodhi, } \\
\text { 2013), }\end{array}$ \\
\hline & 1-Commodity Derivatives (COMD) & DERV1 & $\gamma_{m=1}$ & $\begin{array}{l}\text { Dummy variable, if } \\
\text { Company use } 1 \text { otherwise } 0\end{array}$ & (Bartram et al., 2011) \\
\hline \multirow{2}{*}{$\begin{array}{l}\text { Proposed } \\
\text { Mediating: } \\
\text { Derivatives } \\
\text { (DERV) }\end{array}$} & $\begin{array}{l}\text { 2- Foreign Currency Derivatives } \\
\text { (FCD) }\end{array}$ & DERV2 & $\gamma_{m 2}$ & $\begin{array}{l}\text { Dummy variable, if } \\
\text { Company use } 1 \text { otherwise } 0\end{array}$ & $\begin{array}{l}\text { (Allayanis et al., } \\
\text { 2012) }\end{array}$ \\
\hline & 3-Interest Rate Derivatives (IRD) & DERV3 & $\gamma_{m}$ & $\begin{array}{l}\text { Dammy variable, if } \\
\text { Company use } 1 \text { otherwise } 0\end{array}$ & $\begin{array}{l}\text { (Allayuanis et al., } \\
\text { 2012) }\end{array}$ \\
\hline \multirow[t]{2}{*}{ Symbol: $\mathrm{M}$} & $\begin{array}{l}\text { 4-Derivatives to Asset } \\
\text { (DERV_ASSET) }\end{array}$ & DERV4 & $\gamma_{\mathrm{a} 4}$ & Derivatives fotal Assets & $\begin{array}{l}\text { (Hentschel \& } \\
\text { Kothari, 2001) }\end{array}$ \\
\hline & 1-Retum on Equity (ROE) & $\begin{array}{l}\text { FP1 } \\
\text { FP2 }\end{array}$ & $\gamma_{y 1}$ & $\begin{array}{l}\text { Net Income/Equity } \\
\text { Farnings Available for }\end{array}$ & (Kimu et al., 2009) \\
\hline $\begin{array}{l}\text { Latent } \\
\text { Endogenous }\end{array}$ & 2- Earnings Per Share (EPS) & & $\gamma_{v_{2}}$ & $\begin{array}{l}\text { Conmon Stockholders/No } \\
\text { of common shares } \\
\text { outstanding }\end{array}$ & Ahmed et al. (2012) \\
\hline $\begin{array}{l}\text { Financial } \\
\text { Performance } \\
\text { (FIN_PERF) } \\
\text { Symbol: } \eta\end{array}$ & 3-Tobin Q (TOBINQ) & FP3 & rys & $\begin{array}{l}\text { Total Book Value of } \\
\text { Assets-Book Value of } \\
\text { Equity - Market Value of } \\
\text { Equity/Total Book Value of } \\
\text { Assets. }\end{array}$ & $\begin{array}{l}\text { (Allayannis et al., } \\
\text { 2012; Stank, 2013) }\end{array}$ \\
\hline \multicolumn{2}{|c|}{ Fianacial Performance } & & 9 & \multirow{2}{*}{\multicolumn{2}{|c|}{$\begin{array}{l}\text { This siga represents financial performance after the } \\
\text { impact of derivative usage in H3. } \\
\text { Distarbance term in the SEM model. }\end{array}$}} \\
\hline \multicolumn{3}{|c|}{ Random Disturbance Term } & $E_{1}$ & & \\
\hline
\end{tabular}

\section{Theoretical Model}

We follow the criteria of Helm et at. (2010) and Baron and Kenny (1986) to confirm the mediation and test hypothesis from $\mathrm{H} 1$ to $\mathrm{H} 4$ by applying Partial Least Square, Structural Equation Modeling (PLS-SEM) which is a suitable technique in finance (Fornell, 1984). We used PLS-Smart 3.0 software for our analysis of six years from 2014 to 2009. One of the key advantages of PLS-SEM is that it does not require the non-normality of data (Hair et al., 2012). Further, we consider the constructs are formative because according to Hair et al. (2009) mostly finance and business construct are formative. Moreover, the formative indicators are non-correlated (Chin, 1998), and Cronbach Alpha is not required for formative constructs (Bollen, 1989). We present our PLS-SEM and theoretical model in Figure A below.

\section{Partial Least Square, Structural Equation Modeling}

The PLS-SEM analysis consists of two models; (i) measurement model and (ii) structural model. The details of the models are as follows.

(i) Measurement Model: The measurement model of latent constructs in mathematical term; 


$$
\begin{gathered}
\xi=\gamma \mathrm{x} 1 \mathrm{X} 1+\gamma \mathrm{x} 2 \mathrm{X} 2+\gamma \mathrm{x} 3 \mathrm{X} 3+\gamma \mathrm{x} 4 \mathrm{X} 4+\gamma \mathrm{x} 5 \mathrm{X} 5+\varepsilon 1 \\
\bigotimes=\gamma \mathrm{m} 1 \mathrm{M} 1+\gamma \mathrm{m} 2 \mathrm{M} 2+\gamma \mathrm{m} 3 \mathrm{M} 3+\gamma \mathrm{m} 4 \mathrm{M} 4+\varepsilon 2 \\
\eta=\gamma \mathrm{y} 1 \mathrm{Y} 1+\gamma \mathrm{y} 2 \mathrm{Y} 2+\gamma \mathrm{y} 3 \mathrm{Y} 3+\varepsilon 3
\end{gathered}
$$

(ii) Structural Model: The four hypotheses, H1 to H4 are presented in mathematical term;

$$
\mathrm{H} 1: \eta=\beta_{0(1)}+\tau \xi+\varepsilon 1
$$

$\mathrm{H} 2: \mathrm{M}=\beta_{0(2)}+\alpha \xi+\varepsilon_{2}$

H3: $\phi=\beta_{0(3)}+\alpha \xi+\beta_{1} \mathrm{M}+\varepsilon_{3}$

$\mathrm{H} 4: \eta=\beta_{0(4)}+\tau \xi+\beta_{1} \mathrm{M}+\beta_{2} \phi+\varepsilon_{4}$

Table 3: Details of Variables

H1: (CORP_GOV $\rightarrow$ FIN_PERF)

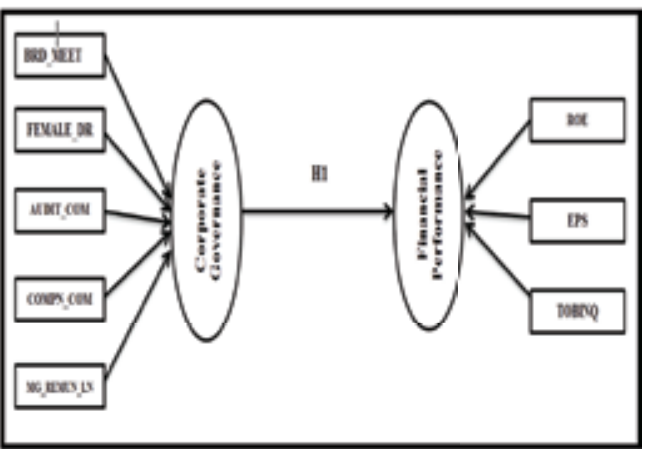

H3: (DERV $\rightarrow$ FIN PERF)

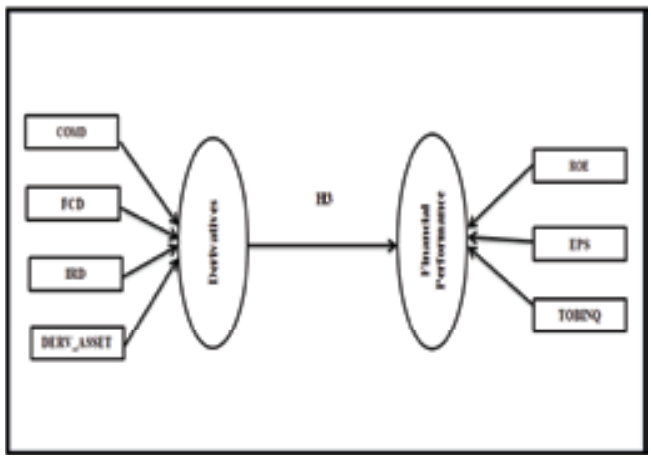

H2: (CORP_GOV $\rightarrow$ DERV)

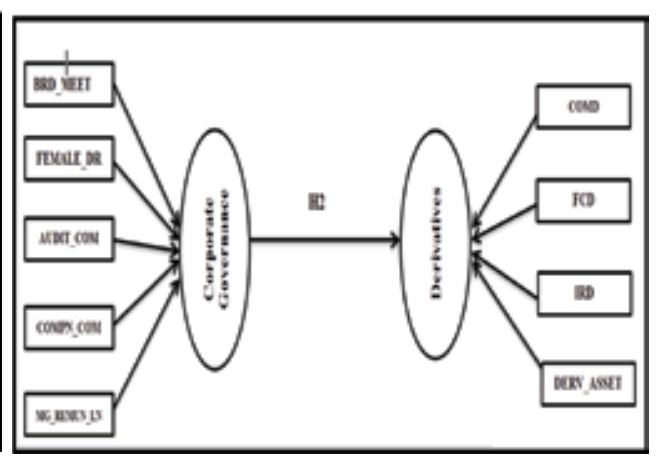

H4: (CORP_GOV $\rightarrow$ DERV $\rightarrow$ FIN_PERF)

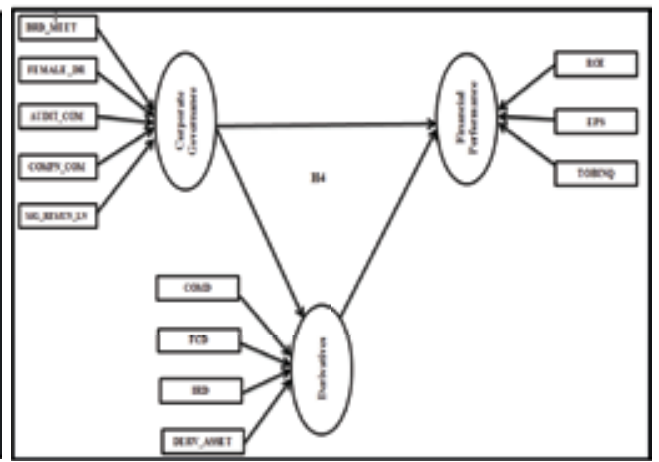

\section{METHODOLOGY AND DATA ANALYSIS}

We follow the criteria of Helm et at. (2010), and Baron and Kenny (1986) to confirm the mediation and test hypothesis from H1 to H4 by applying Partial Least Square, Structural Equation Modeling (PLS-SEM). We present the details of our methodology below. 


\section{Sample Characteristics, Selection and Data Collection}

NYSE is one of the world largest exchange has a market capitalization in May 2015 is 19.69 trillion dollars. The NYSE U.S. 100 Index selected for this study because NYSE has its own corporate governance rules and guidelines for the listing of companies. The financial corporates excluded because they have motives of speculations and trading of derivatives, yet the study sample size was confined to 85 and the number of observations was 6120 . This study is based on quantitative secondary data of six years from 2009 to 2014, published annually. The data collected from the proxy statement (DEF 14A), annual reports (Form 10-K) and Market Watch database.

\section{Data Analysis}

According to assumptions of PLS-SEM the different tests are performed to confirm the relationship presented in this study.

\section{Descriptive Statistics}

The descriptive statistics results are given in Table 3. The average values of board meetings and management remuneration reflect the importance of corporate governance for U.S. corporates. Moreover, reasonable mean values of derivatives to asset ratio show that a considerable number of derivatives contracts used corporates as a hedging tool.

\section{Multicollinearity among constructs}

The multicollinearity among formative constructs creates the problem of unstable weights and must be eliminated and checked through the Variance Inflation Factor (VIF) (Cenfetelli \& Bassellier, 2009) as given in Table 4. According to Kleinbaum et al. (1988), the VIF value should be less than 10 .

\section{Multicollinearity among indicators}

The multicollinearity among indicators checked through bivariate correlation, and all indicators have less than 0.90 correlations, as given in Tables 5 to 10. If the correlation coefficient is greater than 0.90 , multicollinearity exists among indicators (Tabachnick \& Fidell, 1996; Pallant, 2002). 


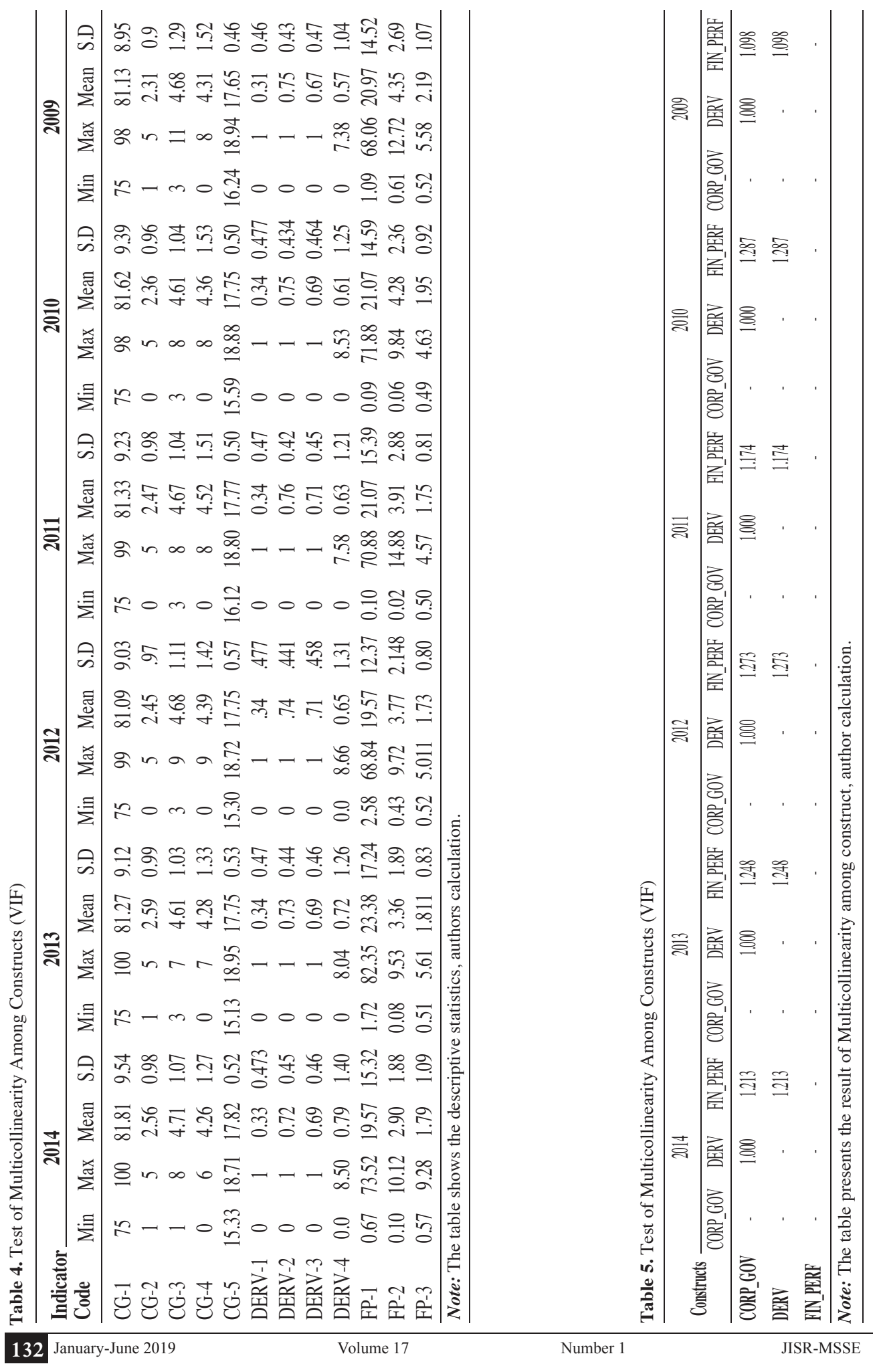


Table 6. Correlation Test Matric (2014)

\begin{tabular}{cccccccccccccc}
\hline No & Indicator Code & $\mathbf{1}$ & $\mathbf{2}$ & $\mathbf{3}$ & $\mathbf{4}$ & $\mathbf{5}$ & $\mathbf{6}$ & $\mathbf{7}$ & $\mathbf{8}$ & $\mathbf{9}$ & $\mathbf{1 0}$ & $\mathbf{1 1}$ & $\mathbf{1 2}$ \\
\hline 1 & CG-1 & 1 & & & & & & & & & & \\
2 & CG-2 & 0.15 & 1 & & & & & & & & & \\
3 & CG-3 & 0.065 & 0.069 & 1 & & & & & & & & \\
4 & CG-4 & 0.148 & -0.16 & $.229^{*}$ & 1 & & & & & & & \\
5 & CG-5 & 0.083 & -0.02 & 0.05 & -0.2 & 1 & & & & & & \\
6 & DERV-1 & 0.191 & 0.107 & 0.122 & 0.213 & 0.11 & 1 & & & & & \\
7 & DERV-2 & 0.153 & 0.068 & 0.023 & 0.19 & -0.01 & 0.106 & 1 & & & & \\
8 & DERV-3 & $.240^{*}$ & 0.044 & 0.151 & $.236^{*}$ & 0.142 & $.248^{*}$ & $.434^{* *}$ & 1 & & & \\
9 & DERV-4 & 0.191 & -0.18 & -0.02 & 0.133 & 0.035 & 0.16 & 0.145 & $.252^{*}$ & 1 & & \\
10 & FP-1 & 0.208 & 0.119 & 0.064 & 0.107 & -0.05 & 0.151 & 0.127 & $.323^{* *}$ & $.301 * *$ & 1 & \\
11 & FP-2 & 0.139 & 0.157 & 0.107 & 0.164 & -0.09 & 0.058 & 0.018 & $.253^{*}$ & 0.102 & $347 * *$ & 1 & \\
12 & FP-3 & $.244 *$ & $.256^{*}$ & -0.1 & 0.024 & -0.1 & 0.156 & 0.085 & -0.07 & -0.01 & 0.131 & -0.01 & 1 \\
\hline
\end{tabular}

Table 7. Correlation Test Matric (2013)

\begin{tabular}{cccccccccccccc}
\hline No & Indicator Code & $\mathbf{1}$ & $\mathbf{2}$ & $\mathbf{3}$ & $\mathbf{4}$ & $\mathbf{5}$ & $\mathbf{6}$ & $\mathbf{7}$ & $\mathbf{8}$ & $\mathbf{9}$ & $\mathbf{1 0}$ & $\mathbf{1 1}$ & $\mathbf{1 2}$ \\
\hline 1 & CG-1 & 1 & & & & & & & & & & \\
2 & CG-2 & 0.047 & 1 & & & & & & & & & \\
3 & CG-3 & 0.052 & 0.19 & 1 & & & & & & & & \\
4 & CG-4 & $.249^{*}$ & -0.01 & 0.167 & 1 & & & & & & & \\
5 & CG-5 & 0.104 & 0.137 & 0.028 & -0.06 & 1 & & & & & & \\
6 & DERV-1 & $.219^{*}$ & 0.074 & 0.079 & $.277^{*}$ & 0.112 & 1 & & & & & \\
7 & DERV-2 & 0.176 & 0.149 & 0.028 & 0.11 & -0.02 & 0.103 & 1 & & & & \\
8 & DERV-3 & 0.18 & 0.111 & $.221^{*}$ & 0.141 & 0.151 & 0.208 & $.458^{* *}$ & 1 & & & \\
9 & DERV-4 & 0.187 & -0.11 & 0.178 & $.232^{*}$ & 0.081 & 0.112 & 0.084 & $.279 *$ & 1 & & \\
10 & FP-1 & 0.105 & 0.176 & -0.05 & 0.101 & 0.014 & 0.077 & 0.026 & 0.198 & 0.06 & 1 & \\
11 & FP-2 & 0.077 & -0.1 & 0.043 & 0.117 & 0.113 & $.223^{*}$ & -0.08 & 0.137 & 0.111 & 0.075 & 1 & \\
12 & FP-3 & 0.206 & 0.135 & -0.12 & -0.05 & -0.08 & -0.04 & -0.02 & 0.064 & -0.09 & $.383^{* *}$ & -0.16 & 1 \\
\hline
\end{tabular}

Table 8. Correlation Test Matric (2012)

\begin{tabular}{cccccccccccccc}
\hline No & Indicator Code & $\mathbf{1}$ & $\mathbf{2}$ & $\mathbf{3}$ & $\mathbf{4}$ & $\mathbf{5}$ & $\mathbf{6}$ & $\mathbf{7}$ & $\mathbf{8}$ & $\mathbf{9}$ & $\mathbf{1 0}$ & $\mathbf{1 1}$ & $\mathbf{1 2}$ \\
\hline 1 & CG-1 & 1 & & & & & & & & & & \\
2 & CG-2 & 0.032 & 1 & & & & & & & & & \\
3 & CG-3 & 0.107 & -0.01 & 1 & & & & & & & & \\
4 & CG-4 & $.269^{*}$ & -0.067 & $.469^{* *}$ & 1 & & & & & & & \\
5 & CG-5 & 0.145 & 0.117 & 0.115 & 0.101 & 1 & & & & & & \\
6 & DERV-1 & 0.164 & 0.027 & 0.072 & $.241^{*}$ & 0.189 & 1 & & & & & \\
7 & DERV-2 & $.219^{*}$ & 0.079 & 0.194 & 0.048 & 0.003 & 0.085 & 1 & & & & \\
8 & DERV-3 & $.274^{*}$ & 0.165 & $.234^{*}$ & 0.195 & 0.088 & $.247^{*}$ & $.444^{* *}$ & 1 & & & \\
9 & DERV-4 & 0.183 & -0.098 & $.356^{* *}$ & $.346^{* *}$ & 0.13 & 0.154 & 0.036 & $.251^{*}$ & 1 & & \\
10 & FP-1 & -0.009 & $.232^{*}$ & -0.09 & -0.009 & 0.001 & -0.027 & 0.036 & 0.122 & -0.131 & 1 & & \\
11 & FP-2 & 0.176 & -0.087 & 0.055 & $.265^{*}$ & 0.115 & 0.147 & -0.148 & 0.114 & 0.181 & 0.116 & 1 & \\
12 & FP-3 & 0.192 & 0.065 & -0.048 & 0.11 & 0.045 & 0 & -0.015 & 0.017 & -0.092 & $301 * *$ & -0.001 & 1 \\
\hline
\end{tabular}

* Level of Sig. at 10\% (1.645) * * Level of Sig. at 5\% (1.96) *** Level of Sig.at 1\% (2.576)

\begin{tabular}{llll}
\hline JISR-MSSE & Volume 17 & Number 1 & January-June 2019 \\
\hline
\end{tabular}


Table 9. Correlation Test Matric (2011)

\begin{tabular}{cccccccccccccc}
\hline No & Indicator Code & $\mathbf{1}$ & $\mathbf{2}$ & $\mathbf{3}$ & $\mathbf{4}$ & $\mathbf{5}$ & $\mathbf{6}$ & $\mathbf{7}$ & $\mathbf{8}$ & $\mathbf{9}$ & $\mathbf{1 0}$ & $\mathbf{1 1}$ & $\mathbf{1 2}$ \\
\hline 1 & CG-1 & 1 & & & & & & & & & & & \\
2 & CG-2 & -0.07 & 1 & & & & & & & & & \\
3 & CG-3 & -0.034 & 0.025 & 1 & & & & & & & & \\
4 & CG-4 & 0.135 & -0.093 & $.381^{* *}$ & 1 & & & & & & & \\
5 & CG-5 & 0.11 & $.271^{*}$ & 0.031 & -0.027 & 1 & & & & & & \\
6 & DERV-1 & 0.182 & -0.042 & 0.085 & 0.164 & 0.158 & 1 & & & & & \\
7 & DERV-2 & $.301^{* *}$ & 0.012 & 0.199 & 0.135 & -0.078 & 0.107 & 1 & & & & \\
8 & DERV-3 & $.313^{* *}$ & 0.126 & $.219^{*}$ & 0.187 & 0.121 & $.247 *$ & $.372^{* *}$ & 1 & & & \\
9 & DERV-4 & 0.095 & -0.041 & 0.172 & $.244^{*}$ & -0.025 & 0.052 & 0.116 & $.241^{*}$ & 1 & & \\
10 & FP-1 & -0.036 & 0.078 & 0.082 & 0.06 & 0.087 & -0.045 & 0.029 & 0.143 & $.231^{*}$ & 1 & \\
11 & FP-2 & 0.19 & -0.077 & $0.135^{*}$ & 0.204 & 0.199 & -0.116 & -0.012 & 0.156 & $343^{* *}$ & 0.164 & 1 & \\
12 & FP-3 & 0.048 & 0.035 & -0.078 & 0.041 & 0.007 & -0.003 & -0.02 & 0.009 & 0.012 & $.392^{* *}$ & 0.009 & 1 \\
\hline
\end{tabular}

Table 10. Correlation Test Matric (2010)

\begin{tabular}{cccccccccccccc}
\hline No & Indicator Code & $\mathbf{1}$ & $\mathbf{2}$ & $\mathbf{3}$ & $\mathbf{4}$ & $\mathbf{5}$ & $\mathbf{6}$ & $\mathbf{7}$ & $\mathbf{8}$ & $\mathbf{9}$ & $\mathbf{1 0}$ & $\mathbf{1 1}$ & $\mathbf{1 2}$ \\
\hline 1 & & CG-1 & 1 & & & & & & & & & & \\
2 & CG-2 & -0.028 & 1 & & & & & & & & & \\
3 & CG-3 & 0.031 & 0.036 & 1 & & & & & & & & \\
4 & CG-4 & 0.155 & -0.051 & $.437^{* *}$ & 1 & & & & & & & \\
5 & CG-5 & -0.074 & 0.07 & 0.039 & -0.084 & 1 & & & & & & \\
6 & DERV-1 & $.226^{*}$ & -0.093 & 0.006 & 0.088 & -0.04 & 1 & & & & & \\
7 & DERV-2 & $.339^{* *}$ & -0.01 & 0.153 & 0.065 & -0.136 & 0.125 & 1 & & & & \\
8 & DERV-3 & $.364^{* *}$ & 0.066 & 0.12 & 0.125 & -0.019 & $.262^{*}$ & $.389 * *$ & 1 & & & \\
9 & DERV-4 & 0.072 & -0.028 & $.257^{*}$ & $.257^{*}$ & -0.085 & 0.013 & 0.033 & $.263^{*}$ & 1 & & \\
10 & FP-1 & -0.009 & 0.089 & $0.061^{*}$ & -0.028 & -0.037 & 0.051 & -0.004 & 0.15 & 0 & 1 & & \\
11 & FP-2 & 0.045 & -0.121 & 0.159 & 0.142 & -0.081 & 0.015 & 0.015 & 0.135 & $.221^{*}$ & $.289^{* *}$ & 1 & \\
12 & FP-3 & 0.068 & 0.038 & -0.081 & 0.012 & -0.023 & -0.018 & -0.094 & 0.008 & -0.124 & $.451^{* *}$ & -0.101 & 1 \\
\hline
\end{tabular}

Table 11. Correlation Test Matric (2009)

\begin{tabular}{cccccccccccccc}
\hline No & Indicator Code & $\mathbf{1}$ & $\mathbf{2}$ & $\mathbf{3}$ & $\mathbf{4}$ & $\mathbf{5}$ & $\mathbf{6}$ & $\mathbf{7}$ & $\mathbf{8}$ & $\mathbf{9}$ & $\mathbf{1 0}$ & $\mathbf{1 1}$ & $\mathbf{1 2}$ \\
\hline 1 & CG-1 & 1 & & & & & & & & & & \\
2 & CG-2 & -0.088 & 1 & & & & & & & & & \\
3 & CG-3 & 0.039 & $.228^{*}$ & 1 & & & & & & & & \\
4 & CG-4 & 0.189 & -0.181 & 0.213 & 1 & & & & & & & \\
5 & CG-5 & 0.121 & $.308^{* *}$ & 0.151 & -0.001 & 1 & & & & & & \\
6 & DERV-1 & $.260^{*}$ & -0.084 & 0.085 & 0.051 & 0.039 & 1 & & & & & \\
7 & DERV-2 & $.247^{*}$ & 0.104 & 0.177 & 0.026 & 0.018 & 0.143 & 1 & & & & \\
8 & DERV-3 & 0.17 & 0.212 & $.216^{*}$ & 0.075 & 0.061 & 0.194 & $.411^{* *}$ & 1 & & & \\
9 & DERV-4 & 0.072 & -0.123 & $.235^{*}$ & $.218^{*}$ & -0.04 & 0.162 & 0.169 & 0.171 & 1 & & \\
10 & FP-1 & 0.019 & 0.009 & 0.051 & 0.151 & -0.072 & -0.059 & 0.033 & 0.084 & -0.092 & 1 & \\
11 & FP-2 & -0.005 & $-.262^{*}$ & 0.017 & $.219^{*}$ & 0.007 & -0.128 & -0.074 & -0.017 & 0.199 & 0.07 & 1 \\
12 & FP-3 & -0.006 & -0.024 & 0.013 & 0.03 & -0.03 & 0.089 & 0.018 & 0.105 & -0.091 & $.409 * *$ & -0.104 & 1 \\
\hline
\end{tabular}

* Level of Sig. at 10\% (1.645) ** Level of Sig. at 5\% (1.96) *** Level of Sig.at 1\% (2.576) 


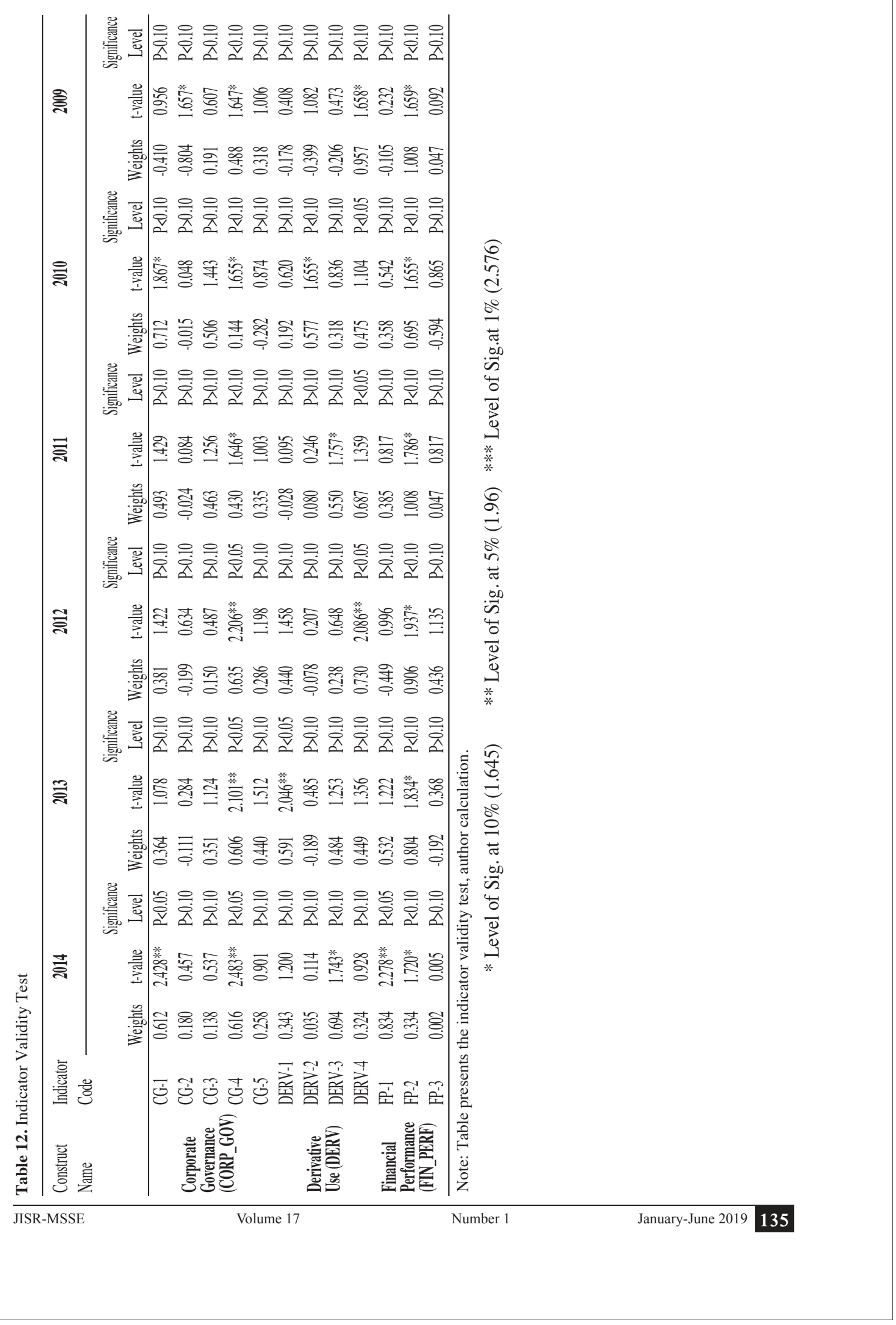


Table 13. Indicator Reliability Test

\begin{tabular}{lccccccc}
\hline Construct Name & Indicator & 2014 & 2013 & 2012 & 2011 & 2010 & 2009 \\
\cline { 3 - 7 } & Code & VIF & VIF & VIF & VIF & VIF & VIF \\
\hline & CG-1 & 1.073 & 1.084 & 1.097 & 1.066 & 1.029 & 1.094 \\
& C2G-2 & 1.079 & 1.059 & 1.022 & 1.141 & 1.036 & 1.207 \\
Corporate Governance & CG-3 & 1.080 & 1.069 & 1.291 & 1.189 & 1.244 & 1.158 \\
(CORP_GOV) & CG-4 & 1.191 & 1.106 & 1.376 & 1.218 & 1.276 & 1.144 \\
& CG-5 & 1.073 & 1.038 & 1.047 & 1.155 & 1.031 & 1.170 \\
& & & & & & & \\
Derivative Use & DERV-1 & 1.077 & 1.049 & 1.076 & 1.065 & 1.078 & 1.061 \\
(DERV) & DERV-2 & 1.235 & 1.269 & 1.255 & 1.162 & 1.186 & 1.222 \\
& DERV-3 & 1.345 & 1.402 & 1.395 & 1.279 & 1.351 & 1.242 \\
Financial Performance & DERV-4 & 1.081 & 1.091 & 1.085 & 1.062 & 1.085 & 1.060 \\
(FIN_PERF) & FP-1 & 1.161 & 1.198 & 1.116 & 1.219 & 1.463 & 1.220 \\
& FP-2 & 1.141 & 1.048 & 1.015 & 1.032 & 1.178 & 1.027 \\
& FP-3 & 1.021 & 1.221 & 1.101 & 1.186 & 1.355 & 1.227 \\
\hline Note: Table shows the indicatoryyyyyy reliability test, authors calculation. & & & &
\end{tabular}

Note: Table shows the indicator reliability test, authors calculation.

\section{Analysis of Structural Model}

As per requirement of PLS-SEM the analysis of the structural model is done.

\section{Path Coefficient $(\beta)$}

The path coefficient for H1 is significant in years 2014, 2013 2012, 2011, and 2010 ( $\beta=, 0.442$, $0.332,0.392,0.388,0.256)$ and insignificant in year $2009(\beta=, 0.347$; $\mathrm{t}$-value $=0.786 ; \mathrm{P}>0.10$,$) .$ The first condition of mediation is acceptable for years 2014, 2012, 2011, and 2010, however as per criteria of Chin (1998) beta coefficient accepted for all six years 2009-2014 because its values are greater or equal to 2.0 .

The path coefficient for $\mathrm{H} 2$ remains significant in all six years 2014, 2013, 2012, 2011, 2010 and 2009 ( $\beta=0.445,0.456,0.503,0.496,0.438,0.408)$. The second condition of mediation accepted for all years 2009-2014 and beta coefficient values are greater than 0.3 .

The path coefficient for H3 remains significant in years 2014, 2013, 2012, 2011, 2010 ( $\beta$ $=0.432,0.332,0.317,0.446,0.250$; and insignificant in years $2009(\beta=0.299)$. The third condition for mediation accepted for years 2014, 2013, 2012, 2011 and 2010 and the beta coefficient is acceptable in all six years 2014 to 2009. According to criteria of Baron and Kenny (1986) as discussed in introduction section after analyzing the first three conditions (H1 to H3) the fourth (H4) to be analyzed for those years which satisfy the first three conditions as given in Figures 1 to 25.

The H1, H2, H3 are accepted for 2014, 2013, 2012, 2011, 2010 and rejected for the year 2009. Now the H4 is tested for all years to check the indirect (mediating) effect of corporate governance passing through derivatives usage on financial performance. The result as given in Tables 13 to 18, shows that the relationship proposed is confirmed for four years 2014, 2013, 2011 , and 2010 because VAF-values are 60\%, 66\%, 38\%, 67\% and direct relationship $(\beta)$ $0.099,0.062,0.194,0.041$ is weaken after applying mediation (Helm et at.,2010; Baron and Kenny, 1986). However, it is rejected for two years 2012, 2009 as VAF-values are 9.2\%, $15.62 \%$ and direct relationship after mediation remain strong $0.332,0.281$.

136 January-June $2019 \quad$ Volume $17 \quad$ Number $1 \quad$ JISR-MSSE


Overall Model Estimation and Predictive Relevance (R2 and Q2)

The overall model estimation done through the coefficient of the determinant (R2) which is greater than $10 \%$ is satisfactory to be reported (Bellman, 2003). The predictive relevance testing is done through Stone Gessier predictive relevance test (Q2) and cross-validation redundancy parameter is applied. As per Chin, (1998) Q2 should be greater than zero.

The study result shows that the model constructed well and satisfies the criteria (Fornell and Cha, 1994) as given in tables 13 to 18. The value of R2 and Q2 for H4 for the years 2014, 2013, 2011, and 2010 are acceptable, and it confirms the relationship presented in this study.

\section{Structural Equation Model Analysis- 2014}

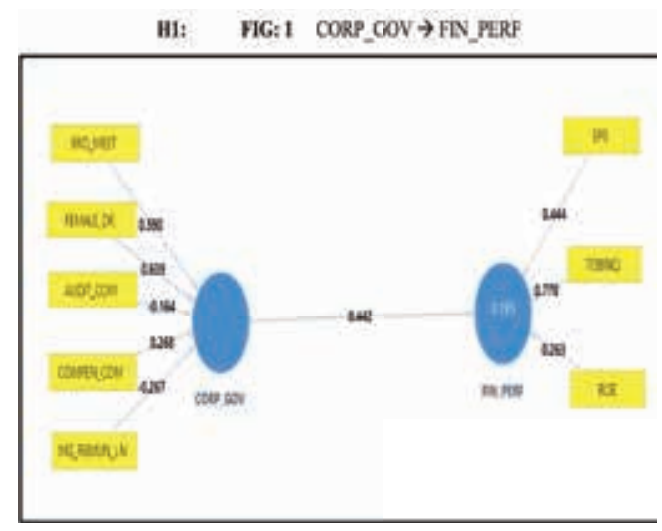

H2: FIG: 2 CORP_GOV $\rightarrow$ DEFV

13: nG:3 DERV $\rightarrow$ HIN_PERF

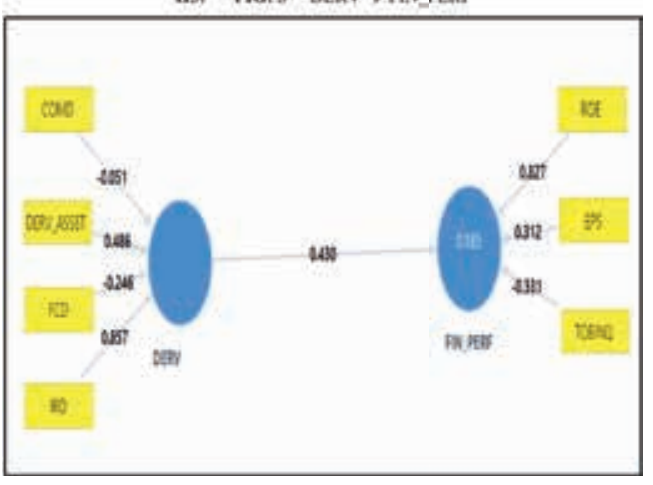

H4: NIG: 4 CORT_GOV $\rightarrow$ DERV $\rightarrow$ FN_PERF

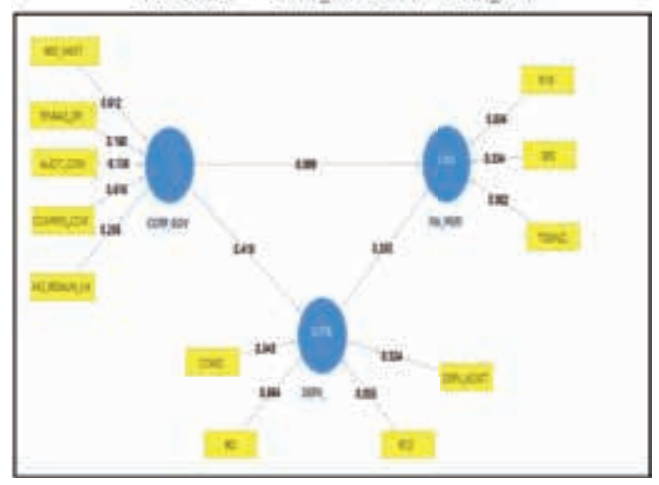


Structural Equation Model Analysis- 2013
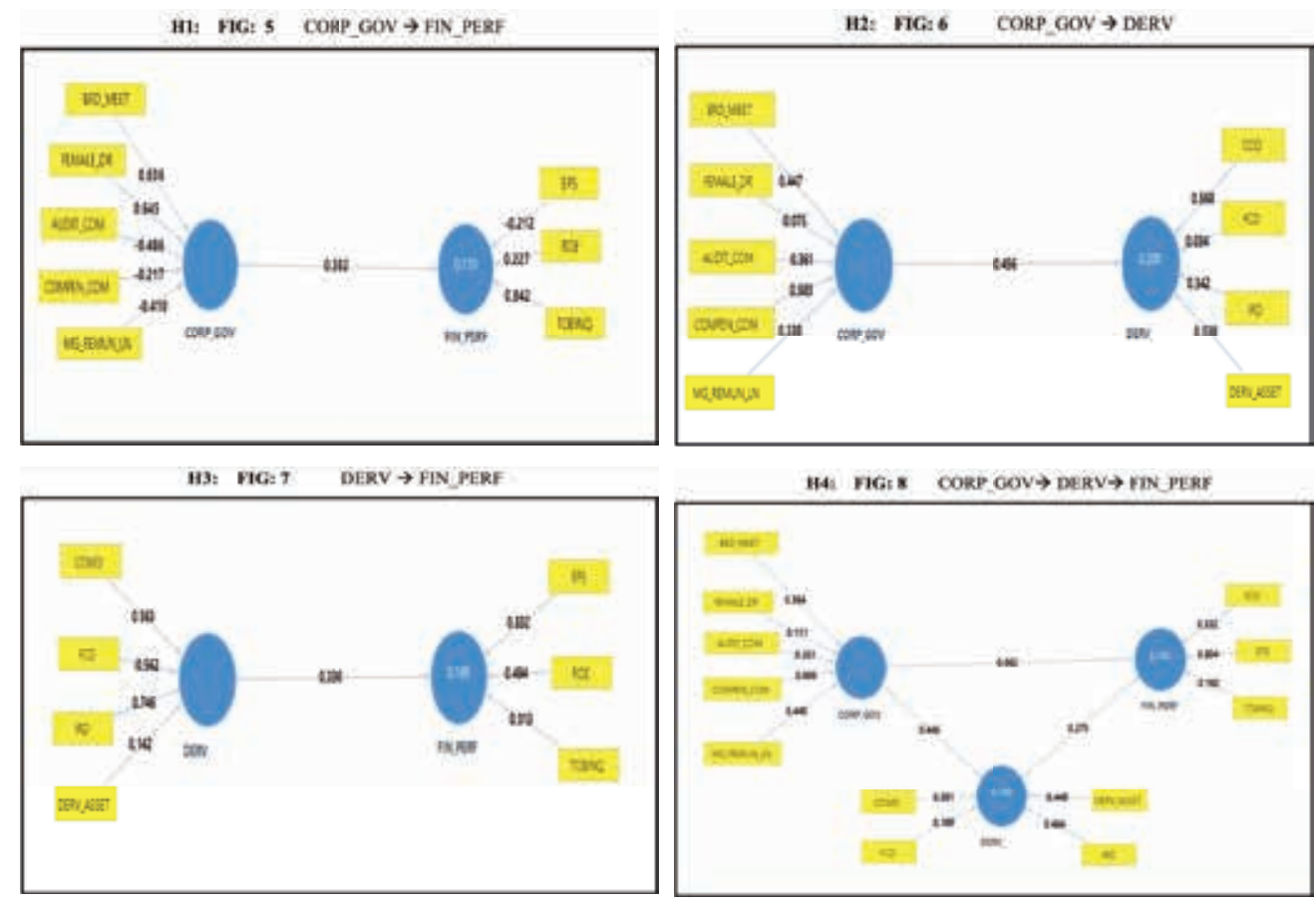

Structural Equation Model Analysis- 2012

HI: HG: 9 CORP GON $\rightarrow$ FIN PERF

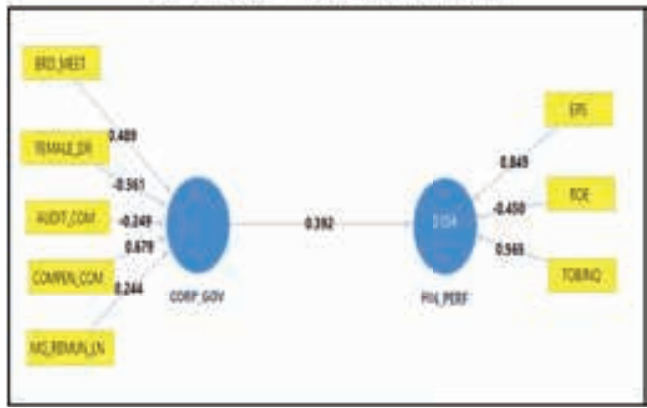

H3i FAGII DERV $\rightarrow$ FIN_PERF

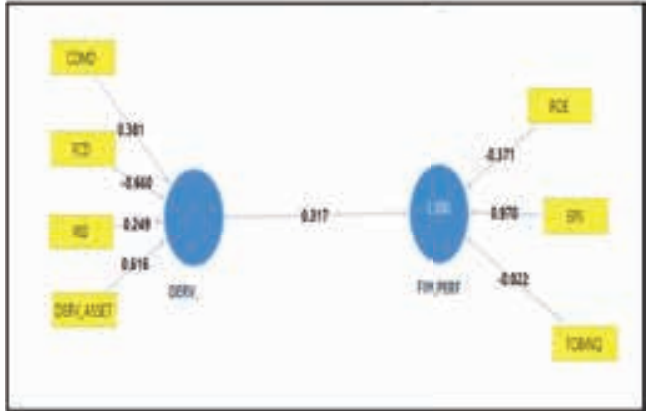

138 January-June 2019

Volume 17
H2: nG: 10 CORP GOV $\rightarrow$ DERV

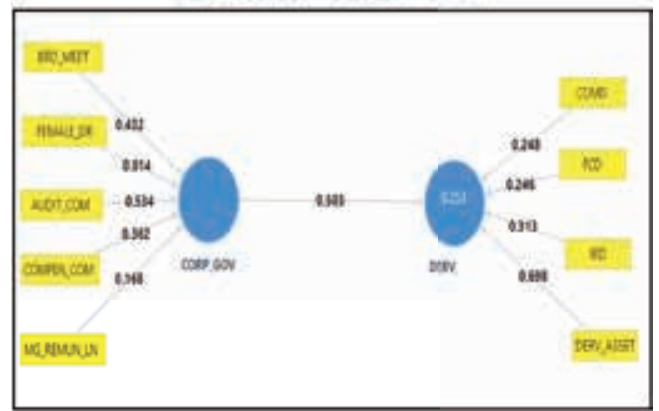

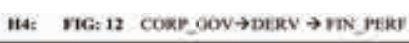

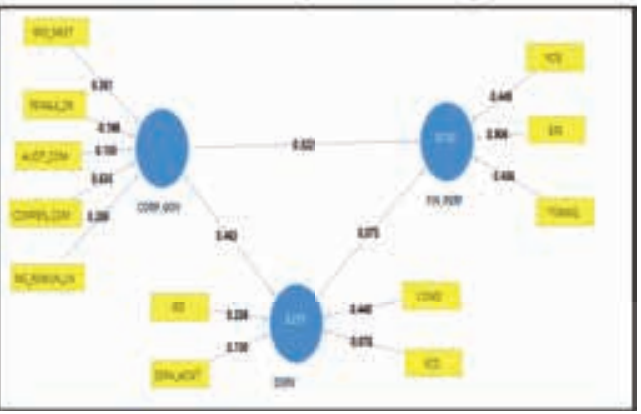

Number 1

JISR-MSSE 
Structural Equation Model Analysis- 2011
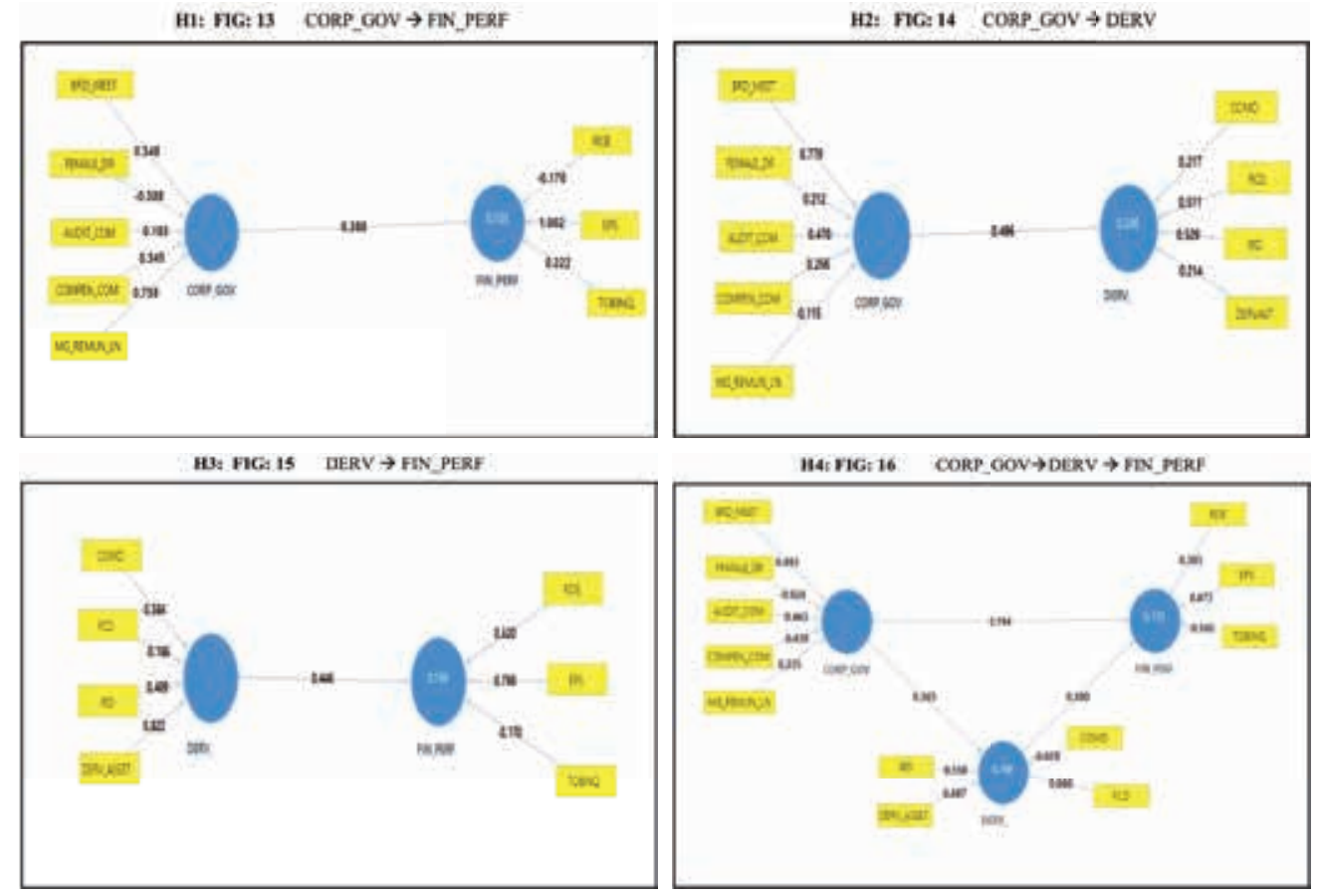

Structural Equation Model Analysis- 2010
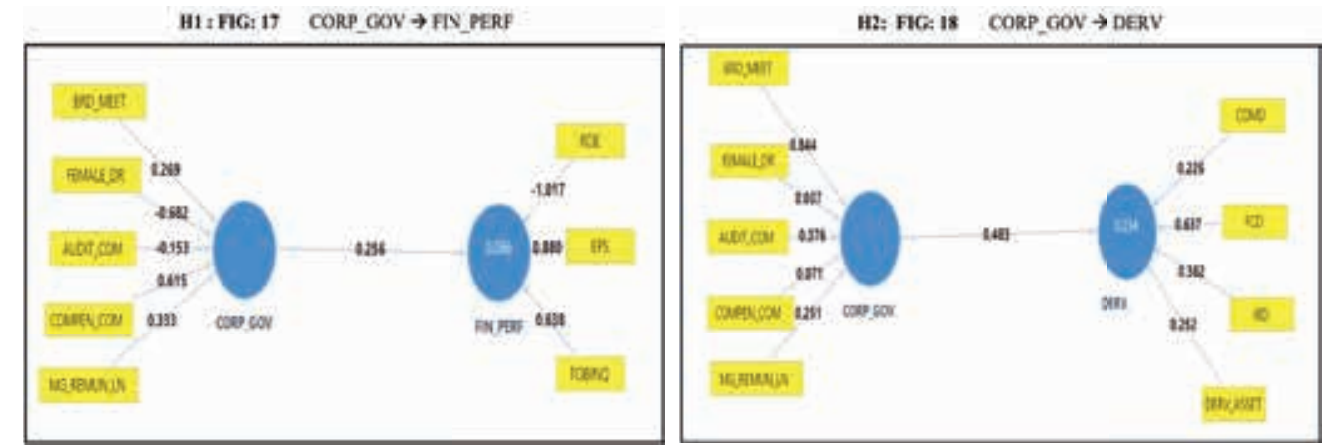

H3: FIG: 19 DERV $\rightarrow$ FIN PEERF

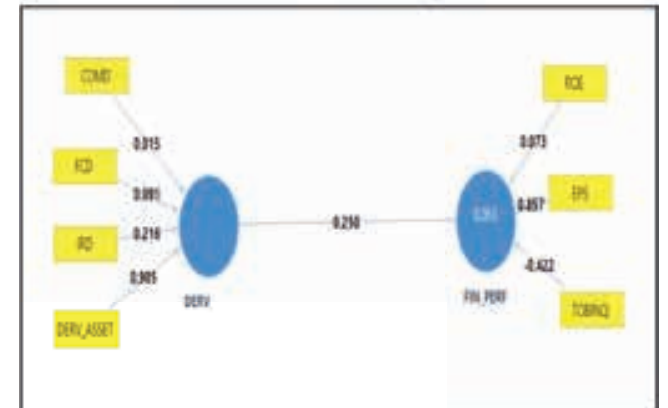

IL: NA: 20 CORP_ CON $\rightarrow$ DERV $\rightarrow$ nN _ PER

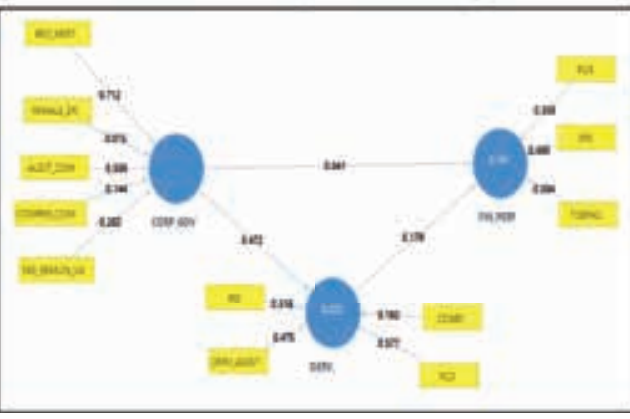

JISR-MSSE

Volume 17

Number 1

January-June $2019 \quad 139$ 
Structural Equation Model Analysis- 2009
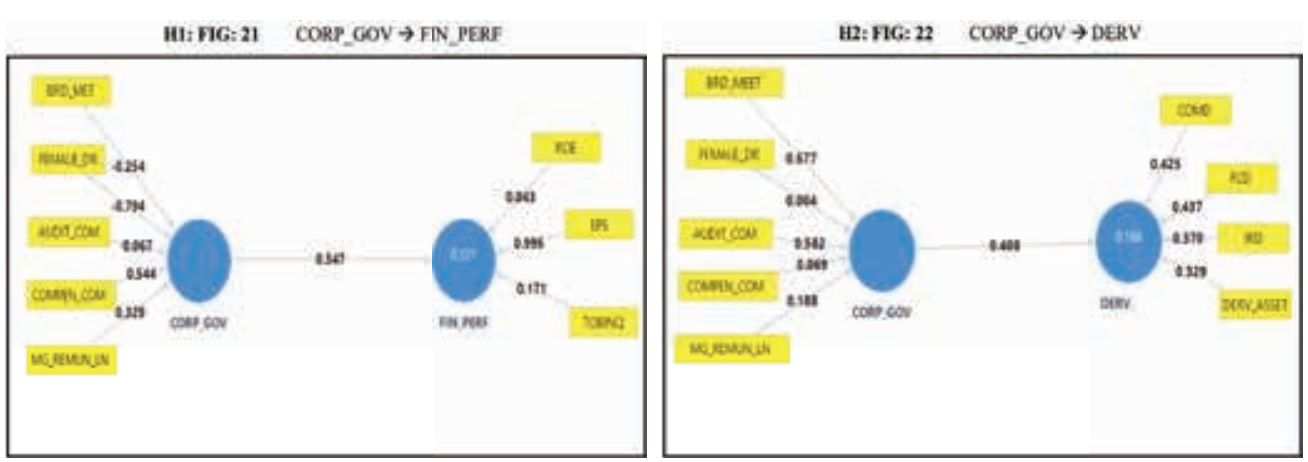

H3: FICA 23 DERY $\rightarrow$ FEX PERS

114 FGG 24 CORP GOV $\rightarrow$ DERN $\rightarrow$ FIN PERF
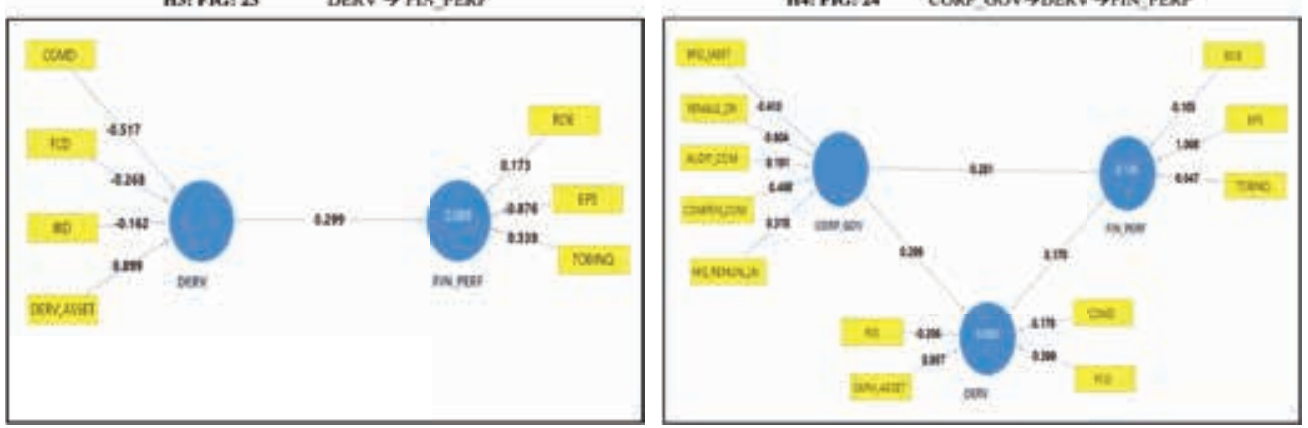

Table 14: Conditions of Mediation (H1 to H3) -2014

\begin{tabular}{c|l|c|c|c|c|c|c}
\hline Hypothesis & Path & Beta Coefficient & t-value & Significance & $\mathrm{R}^{2}$ & $\mathrm{Q}^{2}$ & Criterion \\
\hline H1 & CORP_GOV $\rightarrow$ FIN_PERF & $0.442^{* * *}$ & 3.128 & $\mathrm{P}<0.01$ & 0.195 & 0.049 & $>0.000$ \\
\hline H2 & CORP_GOV $\rightarrow$ DERV & $0.445^{* *}$ & 2.248 & $\mathrm{P}<0.05$ & 0.198 & 0.029 & $>0.000$ \\
\hline H3 & DERV $\rightarrow$ FIN_PERF & $0.432^{* *}$ & 2.059 & $\mathrm{P}<0.05$ & 0.185 & 0.032 & $>0.000$ \\
\hline
\end{tabular}

Mediation (H4)

\begin{tabular}{c|l|c|c|c|c|c|c|c|c}
\hline & & \multicolumn{5}{|c|}{ Beta Coefficient } & $\mathrm{R}^{2}$ & $\mathrm{Q}^{2}$ & Criterion \\
\hline Hypothesis & Path & $\begin{array}{c}\text { Direct } \\
\text { Effect }\end{array}$ & $\begin{array}{c}\text { Indirect } \\
\text { Effect }\end{array}$ & $\begin{array}{l}\text { Total } \\
\text { Effect }\end{array}$ & VAF & Result & & & \\
\hline H4 & $\begin{array}{l}\text { CORP_GOV } \rightarrow \\
\text { DERV } \\
\rightarrow \text { FIN_PERF }\end{array}$ & 0.099 & $\begin{array}{c}0.147 \\
0.429 \mathrm{X} 0.350=\end{array}$ & 0.246 & $60 \%$ & $\begin{array}{c}\text { Partial } \\
\text { Mediation }\end{array}$ & 0.161 & 0.010 & $>0.000$ \\
\hline
\end{tabular}

Note: Table presents the indicator validity test, author calculation. 
Table 15: Conditions of Mediation (H1 to H3) -2013

\begin{tabular}{c|l|c|c|c|c|c|c|c}
\hline Hypothesis & Path & Beta Coefficient & t-value & Significance & $\mathrm{R}^{2}$ & $\mathrm{Q}^{2}$ & Criterion \\
\hline H1 & CORP_GOV $\rightarrow$ FIN_PERF & $0.332^{*}$ & 1.656 & $\mathrm{P}<0.10$ & 0.110 & 0.031 & $>0.000$ \\
\hline H2 & CORP_GOV $\rightarrow$ DERV & $0.456^{* *}$ & 2.445 & $\mathrm{P}<0.05$ & 0.208 & 0.026 & $>0.000$ \\
\hline H3 & DERV $\rightarrow$ FIN_PERF & $0.330^{*}$ & 1.655 & $\mathrm{P}<0.10$ & 0.109 & 0.005 & $>0.000$ \\
\hline \multicolumn{7}{|c|}{ Mediation (H4) } \\
\hline
\end{tabular}

Note. The table represents the Path Coefficient and Overall Model Analysis, author calculation.

Table 16: Conditions of Mediation (H1 to H3) -2012

\begin{tabular}{|c|c|c|c|c|c|c|c|c|c|}
\hline Hypothesis & \multicolumn{2}{|l|}{ Path } & Beta Coefficien & \multicolumn{2}{|c|}{ t-value } & Significance & $\mathrm{R}^{2}$ & $Q^{2}$ & Criterion \\
\hline $\mathrm{H} 1$ & \multicolumn{2}{|c|}{ CORP_GOV $\rightarrow$ FIN_PERF } & $0.392 *$ & \multicolumn{2}{|c|}{1.665} & $\mathrm{P}<0.10$ & 0.154 & 0.007 & $>0.000$ \\
\hline $\mathrm{H} 2$ & \multicolumn{2}{|c|}{ CORP_GOV $\rightarrow$ DERV } & $0.503 * *$ & \multicolumn{2}{|c|}{2.805} & $\mathrm{P}<0.05$ & 0.253 & 0.023 & $>0.000$ \\
\hline $\mathrm{H} 3$ & \multicolumn{2}{|c|}{ DERV $\rightarrow$ FIN_PERF } & $0.317^{*}$ & \multicolumn{2}{|c|}{1.734} & $\mathrm{P}<0.10$ & 0.100 & 0.027 & $>0.000$ \\
\hline \multicolumn{10}{|c|}{ Mediation (H4) } \\
\hline & & \multicolumn{5}{|c|}{ Beta Coefficient } & $\mathrm{R}^{2}$ & $Q^{2}$ & Criterion \\
\hline Hypothesis & Path & $\begin{array}{l}\text { Direct } \\
\text { Effect }\end{array}$ & $\begin{array}{l}\text { Indirect } \\
\text { Effect }\end{array}$ & $\begin{array}{l}\text { Total } \\
\text { Effect }\end{array}$ & VAF & Result & & & \\
\hline $\mathrm{H} 4$ & $\begin{array}{l}\text { CORP_GOV } \rightarrow \\
\text { DERV } \\
\rightarrow \text { FIN_PERF }\end{array}$ & 0.332 & $\begin{array}{c}0.034 \\
0.463 \times 0.073=\end{array}$ & 0.366 & $9.2 \%$ & $\begin{array}{c}\text { No } \\
\text { Mediation }\end{array}$ & 0.131 & 0.023 & $>0.000$ \\
\hline
\end{tabular}

Note. The table represents the Path Coefficient and Overall Model Analysis, author calculation.

* Level of Sig. at 10\% (1.645) ** Level of Sig. at 5\% (1.96) *** Level of Sig.at 1\% (2.576)

Table 17: Conditions of Mediation (H1 to H3) -2011

\begin{tabular}{|c|c|c|c|c|c|c|c|c|c|c|}
\hline Hypothesis & \multicolumn{2}{|l|}{ Path } & Beta Coefficient & \multicolumn{2}{|c|}{ t-value } & \multicolumn{2}{|c|}{ Significance } & $\mathrm{R}^{2}$ & $Q^{2}$ & Criterion \\
\hline $\mathrm{H} 1$ & \multicolumn{2}{|c|}{ CORP_GOV $\rightarrow$ FIN_PERF } & $0.388 *$ & \multicolumn{2}{|c|}{1.793} & \multicolumn{2}{|c|}{$\mathrm{P}<0.10$} & 0.150 & 0.006 & $>0.000$ \\
\hline $\mathrm{H} 2$ & \multicolumn{2}{|c|}{ CORP_GOV $\rightarrow$ DERV } & $0.496 * * *$ & \multicolumn{2}{|c|}{4.941} & \multicolumn{2}{|c|}{$P<0.01$} & 0.246 & 0.022 & $>0.000$ \\
\hline $\mathrm{H} 3$ & \multicolumn{2}{|c|}{ DERV $\rightarrow$ FIN_PERF } & $0.446^{*}$ & \multicolumn{2}{|c|}{1.953} & \multicolumn{2}{|c|}{$\mathrm{P}<0.10$} & 0.199 & 0.027 & $>0.000$ \\
\hline \multicolumn{11}{|c|}{ Mediation (H4) } \\
\hline & & \multicolumn{6}{|c|}{ Beta Coefficient } & $\mathrm{R}^{2}$ & $Q^{2}$ & Criterion \\
\hline Hypothesis & Path & $\begin{array}{l}\text { Direct } \\
\text { Effect }\end{array}$ & $\begin{array}{c}\text { Indirect } \\
\text { Effect }\end{array}$ & $\begin{array}{l}\text { Total } \\
\text { Effect }\end{array}$ & $\mathrm{VA}$ & & Result & & & \\
\hline $\mathrm{H} 4$ & $\begin{array}{l}\text { CORP_GOV } \rightarrow \\
\text { DERV } \\
\rightarrow \text { FIN_PERF }\end{array}$ & 0.194 & $\begin{array}{c}0.116 \\
0.385 \times 0.300=\end{array}$ & 0.310 & $38 \%$ & & $\begin{array}{c}\text { Partial } \\
\text { Mediation }\end{array}$ & 0.172 & 0.013 & $>0.000$ \\
\hline
\end{tabular}

Note. The table represents the Path Coefficient and Overall Model Analysis, author calculation. 
Table 18: Conditions of Mediation (H1 to H3) -2010

\begin{tabular}{c|l|c|c|c|c|c|c}
\hline Hypothesis & Path & Beta Coefficient & t-value & Significance & $\mathrm{R}^{2}$ & $\mathrm{Q}^{2}$ & Criterion \\
\hline H1 & CORP_GOV $\rightarrow$ FIN_PERF & $0.256^{*}$ & 1.657 & $\mathrm{P}<0.10$ & 0.066 & 0.045 & $>0.000$ \\
\hline H2 & CORP_GOV $\rightarrow$ DERV & $0.483^{* *}$ & 2.372 & $\mathrm{P}<0.05$ & 0.234 & 0.054 & $>0.000$ \\
\hline H3 & DERV $\rightarrow$ FIN_PERF & $0.250^{*}$ & 1.659 & $\mathrm{P}<0.10$ & 0.063 & 0.062 & $>0.000$ \\
\hline
\end{tabular}

Mediation (H4)

\begin{tabular}{c|l|c|c|c|c|c|c|c|c}
\hline & & \multicolumn{5}{|c|}{ Beta Coefficient } & $\mathrm{R}^{2}$ & $\mathrm{Q}^{2}$ & Criterion \\
\hline Hypothesis & Path & $\begin{array}{c}\text { Direct } \\
\text { Effect }\end{array}$ & $\begin{array}{c}\text { Indirect } \\
\text { Effect }\end{array}$ & $\begin{array}{l}\text { Total } \\
\text { Effect }\end{array}$ & VAF & Result & & & \\
\hline H4 & $\begin{array}{l}\text { CORP_GOV } \rightarrow \\
\text { DERV } \\
\rightarrow \text { FIN_PERF }\end{array}$ & 0.041 & $\begin{array}{c}0.085 \\
0.472 X 0.179=\end{array}$ & 0.126 & $67 \%$ & $\begin{array}{c}\text { Partial } \\
\text { Mediation }\end{array}$ & 0.141 & 0.032 & $>0.000$ \\
\hline
\end{tabular}

Note. The table represents the Path Coefficient and Overall Model Analysis, author calculation.

Table 19: Conditions of Mediation (H1 to H3) -2011

\begin{tabular}{c|l|c|c|c|c|c|c}
\hline Hypothesis & Path & Beta Coefficient & t-value & Significance & $\mathrm{R}^{2}$ & $\mathrm{Q}^{2}$ & Criterion \\
\hline $\mathrm{H} 1$ & CORP_GOV $\rightarrow$ FIN_PERF & 0.347 & 0.786 & $\mathrm{P}>0.10$ & 0.121 & 0.018 & $>0.000$ \\
\hline $\mathrm{H} 2$ & CORP_GOV $\rightarrow$ DERV & $0.408^{*}$ & 1.656 & $\mathrm{P}<0.10$ & 0.166 & 0.041 & $>0.000$ \\
\hline $\mathrm{H} 3$ & DERV $\rightarrow$ FIN_PERF & 0.299 & 0.072 & $\mathrm{P}>0.10$ & 0.089 & 0.039 & $>0.000$ \\
\hline
\end{tabular}

Mediation (H4)

\begin{tabular}{c|l|c|c|c|c|c|c|c|c}
\hline & & \multicolumn{5}{|c|}{ Beta Coefficient } & $\mathrm{R}^{2}$ & $\mathrm{Q}^{2}$ & Criterion \\
\hline Hypothesis & Path & $\begin{array}{c}\text { Direct } \\
\text { Effect }\end{array}$ & $\begin{array}{c}\text { Indirect } \\
\text { Effect }\end{array}$ & $\begin{array}{c}\text { Total } \\
\text { Effect }\end{array}$ & VAF & Result & & & \\
\hline H4 & $\begin{array}{l}\text { CORP_GOV } \rightarrow \\
\text { DERV } \\
\rightarrow \text { FIN_PERF }\end{array}$ & 0.281 & $\begin{array}{c}0.052 \\
0.299 X 0.170=\end{array}$ & 0.333 & $15 \%$ & $\begin{array}{c}\text { No } \\
\text { Mediation }\end{array}$ & 0.136 & 0.043 & $>0.000$ \\
\hline
\end{tabular}

Note. The table represents the Path Coefficient and Overall Model Analysis, author calculation.

* Level of Sig. at 10\% (1.645) ** Level of Sig. at 5\% (1.96) *** Level of Sig.at 1\% (2.576)

\section{Hypothesis Testing}

The hypothesis $\mathrm{H} 4$ tested as per standard and concluded that derivatives usage work as mediator between the corporate governance and financial performance for years 2014,2013 , 2011, 2010 and rejected for years 2012, 2009.The hypothesis testing detail for all six years given in Table 20. 
Table 20: Hypothesis Testing

\begin{tabular}{|c|c|c|c|c|c|}
\hline Hypothesis & Expected effect & Path Coefficient & Significance & \multicolumn{2}{|c|}{ Confirmed } \\
\hline \multicolumn{6}{|c|}{2014} \\
\hline H1 & \multirow{3}{*}{ Positive } & $0.442^{* * * *}$ & $\mathrm{P}<0.01$ & \multicolumn{2}{|l|}{ Yes } \\
\hline $\mathrm{H} 2$ & & $0.445^{* *}$ & $\mathrm{P}<0.05$ & \multicolumn{2}{|l|}{ Yes } \\
\hline H3 & & $0.430 * *$ & $P<0.05$ & \multicolumn{2}{|l|}{ Yes } \\
\hline \multicolumn{2}{|c|}{ Mediation Testing } & Direet Effect after Mediator & VAF & Results & Confirmed \\
\hline $\mathrm{H} 4$ & Mediation & 0.099 & $60 \%$ & Partial Mediation & Yes \\
\hline \multicolumn{6}{|c|}{2013} \\
\hline $\mathrm{H} 1$ & \multirow{3}{*}{ Positive } & $0.332^{*}$ & $\mathrm{P}<0.01$ & \multicolumn{2}{|l|}{ yes } \\
\hline $\mathrm{H} 2$ & & $0.456 * *$ & $\mathrm{P}<0.05$ & \multicolumn{2}{|l|}{ Yes } \\
\hline $\mathrm{H3}$ & & $0.330^{*}$ & $\mathrm{P}<0.10$ & \multicolumn{2}{|l|}{ Yes } \\
\hline \multicolumn{2}{|c|}{ Mediation Testing } & Direet Effeet after Mediator & VAF & Results & Confirmed \\
\hline $\mathrm{H} 4$ & Mediation & 0.062 & $67 \%$ & Partial Mediation & Yes \\
\hline \multicolumn{6}{|c|}{2012} \\
\hline $\mathrm{HI}$ & Positive & $0.392^{*}$ & $P<0.01$ & \multicolumn{2}{|l|}{ Yes } \\
\hline $\mathrm{H} 2$ & & $0.503 * *$ & $\mathrm{P}<0.05$ & \multicolumn{2}{|l|}{ Yes } \\
\hline H3 & & $0.317^{*}$ & $\mathrm{P}<0.10$ & \multicolumn{2}{|l|}{ Yes } \\
\hline \multicolumn{2}{|c|}{ Mediation Testing } & Direet Effect after Mediator & VAF & Results & Confirmed \\
\hline $\mathrm{H} 4$ & Mediation & 0.332 & $9.2 \%$ & No Mediation & No \\
\hline \multicolumn{6}{|c|}{2011} \\
\hline $\mathrm{H} 1$ & Positive & $0.388^{\circ}$ & $\mathrm{P}<0.01$ & \multicolumn{2}{|l|}{ Yes } \\
\hline $\mathrm{H} 2$ & & $0.496^{* * * *}$ & $\mathrm{P}<0.01$ & \multicolumn{2}{|l|}{ Yes } \\
\hline $\mathrm{H} 3$ & & $0.446^{*}$ & $P<0.1$ & \multicolumn{2}{|l|}{ Yes } \\
\hline \multicolumn{2}{|c|}{ Mediation Testing } & Direct Effect after Mediator & VAF & Results & Confirmed \\
\hline $\mathrm{H} 4$ & Mediation & 0.194 & $38 \%$ & Partial Mediation & Yes \\
\hline \multicolumn{6}{|c|}{2010} \\
\hline HI & Positive & $0.256^{*}$ & $P<0.10$ & \multicolumn{2}{|l|}{ Yes } \\
\hline $\mathrm{H} 2$ & & $0.483 * *$ & $\mathrm{P}<0.05$ & \multicolumn{2}{|l|}{ Yes } \\
\hline $\mathrm{H3}$ & & $0.250^{*}$ & $\mathrm{P}<0.10$ & \multicolumn{2}{|l|}{ Yes } \\
\hline \multicolumn{2}{|c|}{ Mediation Testing } & Direet Effect after Mediator & VAF & Results & Confirmed \\
\hline $\mathrm{H4}$ & Mediation & 0.041 & $67 \%$ & Partial Mediation & Yes \\
\hline & & 2009 & & & \\
\hline H1 & Positive & 0.347 & $\mathrm{P}>0.1$ & No & \\
\hline $\mathrm{H} 2$ & & $0.408^{*}$ & $\mathrm{P}<0.10$ & Yes & \\
\hline $\mathrm{H} 3$ & & 0.299 & $P>0.10$ & No & \\
\hline Mediation T & sting & Direct Effect after Mediator & VAF & Results & Confirmed \\
\hline $\mathrm{H} 4$ & Mediation & 0.281 & $15.62 \%$ & No Mediation & No \\
\hline
\end{tabular}

\section{DISCUSSION AND CONCLUSION}

In this study, it was argued that derivative usage can play a mediating role between corporate governance and financial performance, which checked and verified on non-financial corporates listed on New York Stock Exchange U.S. 100 index. The second-generation multivariable statistical, technique Partial Least Square, Structural Equation Modeling applied through Smart PLS 3.0 to check mediation.

According to the requirement of PLS-SEM, Figure A shows a graphical representation of all four conditions of mediation. The model based on three constructs exogenous variable, corporate governance (board meeting, female director, audit committee, compensation committee, and management remuneration), mediating variable, derivatives usage (mediator)

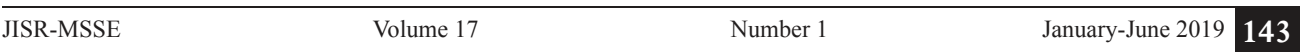


indicators; foreign currency derivatives, interest rate derivatives, commodity derivatives and derivatives to asset ratio) and financial performance (endogenous variable) indicators; return on equity, earning per share and Tobin-Q). The model analyzed for six years from 2009-2014 on a sample of 85 U.S. non-financial corporates. According to criteria of mediation by Helm et at. (2010) and Baron and Kenny (1986) all four conditions are analyzed through PLS-SEM. Hence, it concluded that;

(i) The result is consistent with findings of Ferrer and Banderlipe (2012) that overall corporate governance adds premium in financial performance $(\mathrm{H} 1)$ in five years except for the year 2009, the reason behind no impact of corporate governance in 2009 is financial crises of 2007-2008 (Erkens et al., 2010).

(ii) The results show that corporate governance has a positive impact on derivatives usage (H2) in all six years (Adams et al., 2011; Lel, 2012) because board keep a strong eye on managers and influence them to use derivatives for the benefit of shareholders.

(iii) The results show that overall derivatives usage adds a premium to financial performance (H3) (Clark \& Meftah, 2010; Allayannis and Weston, 2001) by minimizing risk in five years except for the year 2009. The reason behind this non-impact is European financial crises 2007-2008 because derivatives plays two folding role, first they boost the economy by risk hedging but during financial crises they create more chance of losses if before crises financial policy related to derivatives usage is weak (Dodd, 2000) so good corporate governance is must for proper financial policies.

(iv) Further, the concept presented about derivatives usage work as mediator between the corporate governance and financial performance $(\mathrm{H} 4)$ verified by applying PLS-SEM for four years 2014, 2013, 2011, 2010 and no mediating role for two years 2012 and 2009. The reason behind the rejection of hypothesis in 2012 and 2009 is crises like global economic crises in Euro-Zone 2012 and financial crises 2007-2008 (Dodd, 2000). It concluded that strong corporate governance is mandatory to improve financial performance, directly but corporate governance has an additional impact on performance, indirectly (mediation) passing through the use of derivatives as a risk management tool.

Hence, it finalized that corporate governance has a positive impact on financial performance and the mediating role of derivatives usage add more in financial performance. This theory supported by Aebi et al. (2011) who find that strong corporate governance related to risk management is mandatory, as corporate governance alone has no impact on performance during financial crises 2007-2008. The findings of this study recommended to multinational corporates that good corporate governance mechanism and proper risk management system to use derivatives as a hedging tool is mandatory to increase financial performance. The study is not free from a few limitations. The concept offered in this study should be tested in future studies with larger sample size and regional practices of corporate governance in advanced and advancing countries such as Pakistan. Moreover, risk management should be accounted for before generalizing the findings.

\section{REFERENCES}

Adams, M. (2012). Does board independence matter for corporate insurance hedging? Journal of Financial Research, XXXV (3), 451-469.

Adams, M., Lin, C., \& Zou, H. (2011). Chief Executive Officer Incentives, Monitoring, and Corporate Risk Management: Evidence from Insurance Use. The Journal of Risk and Insurance, 78(3), 551-582.

144 January-June $2019 \quad$ Volume $17 \quad$ Number $1 \quad$ JISR-MSSE


Aebi, V., Sabato, G., \& Schmid, M. (2011). Risk management, corporate governance, and bank performance in the financial crisis. Journal of Banking Finance, 36 (12).

Ahmed, S. U., Islam, Z., \& Hasan, I. (2012). Corporate Social Responsibility and Financial Performance Linkage-Evidence from the Banking Sector of Bangladesh. Journal of Organizational Management, 1(1), 14-21.

Allayannis, G., \& Weston, J. P. (2001). The use of foreign currency derivatives and firm market value. Review of Financial Studies, 14(1), 243-276.

Allayannis, G., Lel, U., \& Miller, D. P. (2012). The use of foreign currency derivatives, corporate governance, and firm value around the world. Journal of International Economics, 87(1), 65-79.

Andreev, P., Heart, T., Maoz, H., \& Pliskin, N. (2009). Validating Formative Partial Least Squares (PLS) Models: Methodological Review and Empirical Illustration. International Conference on Information Systems, 1-17.

Ayturk, Y., Gurbuz, A. O., \& Yanik, S. (2016). Corporate derivatives use and firm value: Evidence from Turkey. Borsa Istanbul Review, 16(2), 108-120.

Bae, S. C., Kim, H. S., \& Kwon, T. H. (2018). Currency derivatives for hedging: New evidence on determinants, firm risk, and performance. Journal of Futures Markets, 38(4), 446-467.

Bahoo, S., Khan, S., \& Ahmad, M. (2018). DO DERIVATIVES INCREASE AMERICAN CORPORATE' S FINANCIAL PERFORMANCE? City University Research Journal, 08 (July), 219-235.

Baron, R. M., \& Kenny, D. a. (1986). The moderator-mediator variable distinction in social psychological research: conceptual, strategic, and statistical considerations. Journal of Personality and Social Psychology, 51(6), 1173-1182.

Bartram, S. M., Brown, G. W., \& Conrad, J. (2011). The Effects of Derivatives on Firm Risk and Value Using a large sample of non-financial firms from 47 countries, Review of Financial Studies, 14(1), 243-276.

Bellman, S. (2003). How to use PLS. Graduate School of Management. Working Paper-University of Western Australia, Crawley, July 2003.

Bessembinder, H. (1991). Forward Contracts and Firm Value: Investment Incentive and Contracting Effects. The Journal of Financial and Quantitative Analysis, 26(4).

Black, B., \& Kim, W. (2012). The effect of board structure on firm value: A multiple identification strategies approach using Korean data. Journal of Financial Economics, 104(1), 203-226.

Bodnar, G. M., Marston, R. C., \& Hayt, G. (1998). 1998 Survey of Financial Risk Management by U.S. Non-Financial Firms. Wharton/CIBC world market-Working Paper.

Bollen, K. A. (1989). Structural Equations with Latent Variables. Book Reference.

Bollen, K.A., Lennox, R., 1991. Conventional wisdom on measurement: a structural equation perspective. Psychological Bulletin 110 (2).

Bratton, W. W. (2002). Enron and the Dark Side of Shareholder Value Enron and the Dark Side of Shareholder Value. Working Paper.

Cenfetelli, R. T., \& Bassellier, G. (2009). Interpretation of Formative Measurement in Information Systems Research. Mis Quarterly, 33(4), 689-707.

Chhaochharia, V., \& Grinstein, Y. (2007). Corporate Governance and Firm Value: The Impact of the 2002 Governance Rules. The Journal of Finance, 64 (4).

Chin, W.W. (1998). The Partial Least Square Approach to Structural Equal Modeling, George

\begin{tabular}{llll}
\hline JISR-MSSE & Volume 17 & Number 1 & January-June 2019 \\
\hline
\end{tabular}


Marcoulides (Eds.), Modern Methods for Business Research. Lawrence Erlbaum Associates, N.J.

Clark, E., \& Meftehb, S. (2010). Foreign Currency Derivatives Use, Firm Value and the Effect of the Exposure Profile: Evidence from France. International Journal of Business, 15(2).

Connelly, J. T., Limpaphayom, P., \& Nagarajan, N. J. (2012). Form versus substance: The effect of ownership structure and corporate governance on firm value in Thailand. Journal of Banking and Finance, 36(6), 1722-1743.

Darus, F. (2011). Corporate Governance and Corporate Failure in the Context of Agency Theory. Working paper.

Dey, A. (2008). Corporate Governance and Agency Conflicts. Journal of Accounting Research, 46(5), 1143-1181.

Dodd, R. (2000). The Role of Derivatives in the East Asian Financial Crisis. Economic Policy, 20.

Donohoe, M. P. (2015). The economic effects of financial derivatives on corporate tax avoidance. Journal of Accounting and Economics, 59(1), 1-24.

Erez-gonz, F. P. (2013). Risk Management and Firm Value: Evidence from. The Journal of Finance, LXVIII (5), 2143-2176.

Erkens, D., Hung, M., Matos, P., 2010. Corporate governance in the 2007-2008 financial crisis: evidence from financial institutions worldwide. Working Paper, University of Southern California.

Eurozone crisis explained. (2012, November 7). BBC News. Retrieved from https://www.bbc.com/news/business-13798000.

Faleye, O. (2007). Classified boards, firm value, and managerial entrenchment. Journal of Financial Economics 83, 83.

Ferrer, R. C., \& Banderlipe, M. R. S. (2012). The influence of corporate board characteristics on firm performance of publicly listed property companies in the Philippines. Academy of Accounting and Financial Studies Journal, 16(4), 123-142.

Fiksenbaum, L., Marjanovic, Z., \& Greenglass, E. (2017). Financial threat and individuals' willingness to change financial behavior. Review of Behavioral Finance, 9(2), 128-147.

Fok, R. C. W., Carroll, C., \& Chiou, M. C. (1997). Determinants of Corporate Hedging and Derivatives: A Revisit, 6195(X).

Fornell, C. (1984). A Second Generation of Multivariate Analysis: Classification of Methods and Implications for Marketing Research. Unpublished discussion paper, Graduate School of Business Administration, The University of Michigan.

Fornell, C. and Cha, J. (1994). Partial Least Squares in Advanced Methods of Marketing Research, Bagozzi, R. P. edition. Blackwell, Oxford.

Gupta, P., \& Sharma, A. M. (2014). A Study of the Impact of Corporate Governance Practices on Firm Performance in Indian and South Korean Companies. Procedia-Social and Behavioral Sciences, 133, 4-11.

Hair, J. F., Sarstedt, M., Ringle, C. M., and Mena, J. A. (2012). “An Assessment of the Use of Partial Least Squares Structural Equation Modeling in Marketing Research. Journal of the Academy of Marketing Science, Forthcoming.

Hair, J.F., Black, W.C., Babin, B.J. and Anderson, R.E. (2009). Multivariate Data Analysis, Seventh Edition. Prentice Hall, N.Y.

Helm, S., Eggert, A., Garnefeld, I. (2010). Modeling the impact of corporate reputation on customer satisfaction and loyalty using PLS. Book Chapter Published in Handbook of Partial Least Squares.

146 January-June $2019 \quad$ Volume $17 \quad$ Number $1 \quad$ JISR-MSSE


Helm, S., Eggert, A., Garnefeld, I., 2010. Modeling the impact of corporate reputation on customer satisfaction and loyalty using PLS.

Hentschel, L., \& Kothari, S. P. (2001). Are Corporations Reducing or Taking Risks with Derivatives? The Journal of Financial and Quantitative Analysis, 36(1), 93-118.

Iqbal, M. J., Nawaz, M. S., Bahoo, S., \& Bukhari, A. S. (2017). Impact of Project Teamwork on Project Success in Pakistan Impact of Project Teamwork on Project Success in Pakistan. South Asian Journal of Management Sciences, 11(1), 1-13.

Jackson, G. (2010). Understanding Corporate Governance in the United States. Corporate Governance-Working paper.

Jiang, H., \& Zhang, H. (2018). Regulatory restriction on executive compensation, corporate governance and firm performance: Evidence from China. Asian Review of Accounting, 26(1), 131-152.

Kim, H. T., Papanastassiou, M., \& Nguyen, Q. (2017). Multinationals and the impact of corruption on financial derivatives use and firm value: Evidence from East Asia. Journal of Multinational Financial Management, 39, 39-59.

Kim, J. K., Xiang, J. Y., \& Lee, S. (2009). The impact of IT investment on firm performance in China: An empirical investigation of the Chinese electronics industry. Technological Forecasting and Social Change, 76(5), 678-687.

Kleinbaum, D.G., Kupper, L.L., and Muller K.E. (1988). Applied Regression Analysis and other Multivariate Analysis Methods, PWS-Kent Publishing, Boston, MA. USA.

Kommunuri, J., Narayan, A., Wheaton, M., \& Jandug, L. (2014). Enterprise Risk Management and Firm Performance Empirical evidence from Vietnam. Working Paper.

Leautier, T. (2007). Corporate risk management for value creation: a guide to real-life applications 1st Edition. Risk Books, London, the United Kingdom.

Lel, U. (2012). Currency hedging and corporate governance: A cross-country analysis. Journal of Corporate Finance, 18(2).

Makki, M. A. M., \& Lodhi, S. A. (2013). Impact of Corporate Governance on Corporate Financial Performance. Pakistan Journal of Social Sciences, 33(2), 265-280.

Nawaz, K., \& Ahmad, N. (2017). The Effect of Corporate Governance and Capital Structure on Firms' Performance: Investigation on Petroleum Sector in Pakistan. Journal of Independent Studies and Research-Management, Social Sciences and Economics, 1(15), 51-68.

Nguyen, T., Nguyen, H. G. (Lily), \& Yin, X. (2015). Corporate Governance and Corporate Financing and Investment during the 2007-2008 Financial Crisis. Financial Management, 44(1), 115-146.

NYSE US 100 Index. (2019). Retrieved from https://www.nyse.com/quote/index/NY.ID.

Pallant, J. (2002). Spss Survival Manual.

Paniagua, J., Rivelles, R., \& Sapena, J. (2018). Corporate governance and financial performance $\bigotimes$ : The role of ownership and Board Structure. Journal of Business Research, 89(January), 229-234.

Paniagua, J., Rivelles, R., \& Sapena, J. (2018). Corporate governance and financial performance $\bigotimes$ : The role of ownership and Board Structure. Journal of Business Research, 89(January), 229-234.

Prevost, A. K., Rose, L. C., \& Miller, G. (2000). Derivatives usage and financial risk management in large and small economies: A comparative analysis. Journal of Business Finance and Accounting, 27(5-6), 733-759. 
Raj, A. (2018). Erratum to "Socially responsible governance mechanisms for manufacturing firms in apparel supply chains" [Int. J. Prod. Econ. 196 (2018) 135-149]. International Journal of Production Economics, 200, 15.

Renders, A., Gaeremynck, A., \& Sercu, P. (2010). Corporate-Governance Ratings and Company Performance: A Cross-European Study. Corporate Governance: An International Review, 18(2), 87-106.

Shahwan, M. T. (2015). The effects of corporate governance on financial performance and financial distress: evidence from Egypt. Corporate Governance, 15(5), 641-662.

Shan, Y. G. (2013). Can Internal Governance Mechanisms Prevent Asset Appropriation? Examination of Type I Tunneling in China. Corporate Governance: An International Review, 21(3), 225-241.

Tabachnick, B.G. and Fidell, LS. (1996). Using Multiple Statistics. Harper Collins Publishers, New York, NY.

Velnampy, P. T. (2013). Corporate Governance and Firm Performance区: A Study of Sri Lankan Manufacturing Companies, 4(3), 228-236.

Yang, T., \& Zhao, S. (2014). CEO duality and firm performance: Evidence from an exogenous shock to the competitive environment. Journal of Banking \& Finance, 49, 534-552.

Yilmaz, I. (2018). Corporate Governance and Financial Performance Relationship囚: Case for Oman Companies. Journal of Accounting, Finance, and Auditing Studies, 4(4), 84-106. 